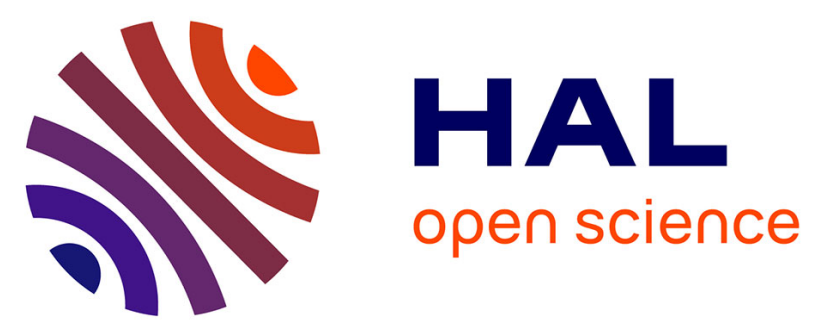

\title{
Mechanisms involved in the death of steatotic WIF-B9 hepatocytes co-exposed to benzo[a]pyrene and ethanol a possible key role for xenobiotic metabolism and nitric oxide
}

Arnaud Tête, Isabelle Gallais, Muhammad Imran, Martine Chevanne, Marie Liamin, Lydie Sparfel, Simon Bucher, Agnès Burel, Normand Podechard, Brice M R Appenzeller, et al.

\section{- To cite this version:}

Arnaud Tête, Isabelle Gallais, Muhammad Imran, Martine Chevanne, Marie Liamin, et al.. Mechanisms involved in the death of steatotic WIF-B9 hepatocytes co-exposed to benzo[a]pyrene and ethanol a possible key role for xenobiotic metabolism and nitric oxide. Free Radical Biology and Medicine, 2018, 129, pp.323-337. 10.1016/j.freeradbiomed.2018.09.042 . hal-01888877

\section{HAL Id: hal-01888877}

\section{https://hal-univ-rennes1.archives-ouvertes.fr/hal-01888877}

Submitted on 9 Nov 2018

HAL is a multi-disciplinary open access archive for the deposit and dissemination of scientific research documents, whether they are published or not. The documents may come from teaching and research institutions in France or abroad, or from public or private research centers.
L'archive ouverte pluridisciplinaire HAL, est destinée au dépôt et à la diffusion de documents scientifiques de niveau recherche, publiés ou non, émanant des établissements d'enseignement et de recherche français ou étrangers, des laboratoires publics ou privés. 


\section{ACCEPTED MANUSCRIPT}

\section{Mechanisms involved in the death of steatotic WIF-B9 hepatocytes co- exposed to benzo[a]pyrene and ethanol: a possible key role for xenobiotic metabolism and nitric oxide}

Arnaud Tête ${ }^{\mathrm{a}}$, Isabelle Gallais ${ }^{\mathrm{a}}$, Muhammad Imran ${ }^{\mathrm{a}}$, Martine Chevanne ${ }^{\mathrm{a}}$, Marie Liamin ${ }^{\mathrm{a}}$, Lydie Sparfel $^{\mathrm{a}}$, Simon Bucher ${ }^{\mathrm{b}}$, Agnès Burel ${ }^{\mathrm{c}}$, Normand Podechard ${ }^{\mathrm{a}}$, Brice MR Appenzeller ${ }^{\mathrm{d}}$, Bernard Fromenty $^{\mathrm{b} 1}$, Nathalie Grova ${ }^{\mathrm{d} 1}$, Odile Sergent ${ }^{\mathrm{a} 1}$, Dominique Lagadic-Gossmann ${ }^{\mathrm{a}{ }^{*}}$

${ }^{a}$ Univ Rennes, Inserm, EHESP, Irset (Institut de recherche en santé, environnement et travail) UMR_S 1085, F-35000 Rennes, France

${ }^{b}$ Univ Rennes, Inserm, Inra, Institut NUMECAN (Nutrition Metabolisms and Cancer) - UMR_S 1241, UMR_A 1341, F-35000 Rennes, France

${ }^{c}$ Univ Rennes, Biosit-UMS 3480, US_S 018, F-35000 Rennes, France

${ }^{d}$ HBRU, Luxembourg Institute of Health, 29, rue Henri Koch, L-4354 Esch-sur-Alzette, Luxembourg

*Corresponding author at Inserm U1085/IRSET, Université Rennes 1, Faculté de Pharmacie, 2 avenue du Professeur Léon Bernard, 35043 Rennes cedex, France. Tel.: +33(0)223234837. dominique.lagadic@univ-rennes1.fr

\section{ABSTRACT}

We previously demonstrated that co-exposing pre-steatotic hepatocytes to benzo[a]pyrene (B[a]P), a carcinogenic environmental pollutant, and ethanol, favored cell death. Here, the intracellular mechanisms underlying this toxicity were studied. Steatotic WIF-B9 hepatocytes, obtained by a 48hsupplementation with fatty acids, were then exposed to $\mathrm{B}[\mathrm{a}] \mathrm{P} / \mathrm{ethanol}(10 \mathrm{nM} / 5 \mathrm{mM}$, respectively) for 5 days. Nitric oxide (NO) was demonstrated to be a pivotal player in the cell death caused by the coexposure in steatotic hepatocytes. Indeed, by scavenging NO, CPTIO treatment of co-exposed steatotic cells prevented not only the increase in DNA damage and cell death, but also the decrease in the activity of CYP1, major cytochrome P450s of B[a]P metabolism. This would then lead to an elevation of $\mathrm{B}[\mathrm{a}] \mathrm{P}$ levels, thus possibly suggesting a long-lasting stimulation of the transcription factor AhR. Besides, as NO can react with superoxide anion to produce peroxynitrite, a highly oxidative compound, the use of FeTPPS to inhibit its formation indicated its participation in DNA damage and

\footnotetext{
${ }^{1}$ equal supervision
} 


\section{ACCEPTED MANUSCRIPT}

cell death, further highlighting the important role of NO. Finally, a possible key role for AhR was pointed out by using its antagonist, $\mathrm{CH}-223191$. Indeed it prevented the elevation of ADH activity, known to participate to the ethanol production of ROS, notably superoxide anion. The transcription factor, NFkB, known to be activated by ROS, was shown to be involved in the increase in iNOS expression. Altogether, these data strongly suggested cooperative mechanistic interactions between $\mathrm{B}[\mathrm{a}] \mathrm{P}$ via $\mathrm{AhR}$ and ethanol via ROS production, to favor cell death in the context of prior steatosis.

Abbreviations : ADH: alcohol dehydrogenase; AU: arbitrary unit; $\mathrm{B}[\mathrm{a}] \mathrm{P}$ : benzo[a]pyrene; CYP: cytochrome P450; CZX: chlorzoxazone; HFD: high fat diet; MDA: malondialdehyde; NAFLD; nonalcoholic fatty liver disease; NASH: nonalcoholic steatohepatitis; NCZX: chlorzoxazone Nglucuronide; OCZX: chlorzoxazone O-glucuronide.

Keywords : NAFLD; liver; AhR; CYP1A1; ADH ; DNA damage; peroxynitrite anion

\section{1-INTRODUCTION}

Hepatic steatosis (fatty liver) and steatohepatitis (characterized by both cell death and inflammation), have been related to diverse etiologic factors, the three major being alcohol, obesity and environmental pollutants [1]. With the growing epidemics of obesity, which predisposes in most cases to steatosis, and due to the number of metabolism-disrupting chemicals present in our environment, a further increase in the prevalence of steatosis and steatohepatitis, and hence related liver diseases (cirrhosis, cancers), is expected to occur in the near future [1-6]. Besides the well-known steatotic effect of alcohol [7], several studies have reported that environmental pollutants would also be involved in the development of fatty liver disease, the so-called toxicant-associated fatty liver disease (TAFLD) [1]. In this context, it has been suggested that the three major etiologies of steatosis as listed above, could interplay to favor the development of steatohepatitis, although this aspect remains largely underexplored [1]. In line with this, our previous work demonstrated that the presence of a prior steatosis enhanced the hepatotoxicity of a co-exposure to ethanol and the well-known environmental carcinogen benzo[a]pyrene $(\mathrm{B}[\mathrm{a}] \mathrm{P})$, both in vitro and in vivo, and favored the appearance of a steatohepatitis-like state, with the development of inflammation [8]. In that study, 


\section{ACCEPTED MANUSCRIPT}

$\mathrm{B}[\mathrm{a}] \mathrm{P}$ was chosen based upon the fact that this carcinogen is a widespread pollutant present in diesel exhaust particles, cigarette smoke and grilled and smoked food, among others $[9,10]$. Even though a direct link between $\mathrm{B}[\mathrm{a}] \mathrm{P}$ exposure and non-alcoholic fatty liver disease (NAFLD) has been mainly evidenced in rodents [11], different epidemiological studies indicate that high meat consumption, especially grilled meat, as well as cigarette smoking, that is, two major routes of $\mathrm{B}[\mathrm{a}] \mathrm{P}$ exposure, are associated with increased risk of NAFLD [12-15]. Besides it is important to stress that, for nonsmokers in developed countries, human dietary exposure to $\mathrm{B}[\mathrm{a}] \mathrm{P}(0.5-320 \mathrm{ng} / \mathrm{day})$ is generally larger than that by inhalation ( $0.15-25 \mathrm{ng} /$ day), thus pointing to food ingestion as the main route of exposure to $\mathrm{B}[\mathrm{a}] \mathrm{P}$ for a large part of the general population [16]. In this context, liver appears as an evident target for $\mathrm{B}[\mathrm{a}] \mathrm{P}$, as already reported notably with respect to liver cancer [17, 18]. Regarding the relevance for focusing on co-exposure to $\mathrm{B}[\mathrm{a}] \mathrm{P}$ and ethanol, it is noteworthy that tobacco smoking and alcohol consumption were found as interacting to favor liver cancer [19, 20], thus supporting our choice for studying the effects of hepatocyte co-exposure to $\mathrm{B}[\mathrm{a}] \mathrm{P}$ and ethanol. However, although we have previously evidenced that such a co-exposure constitutes a second hit to favor the pathological progression of a prior steatosis, notably by increasing cell death [8], the intracellular mechanisms underlying this increase still remained to decipher, especially how $\mathrm{B}[\mathrm{a}] \mathrm{P}$ and ethanol might mechanistically cooperate in this particular context of prior steatosis.

Diverse studies have reported that steatosis could affect xenobiotic metabolism through alterations of the expression of various enzymes related to phases I, II and III [21-24], with expected consequences in terms of chemical toxicokinetics [25]. Nevertheless, except for a proposed role for CYP2E1 and CYP4A in NAFLD, notably via an effect on reactive oxygen species (ROS) production [26-28], the involvement of xenobiotic metabolism in the pathological progression of liver steatosis is still poorly investigated. We recently demonstrated that $\mathrm{B}[\mathrm{a}] \mathrm{P}$ metabolism was globally reduced by coexposing steatotic HepaRG cells to both B[a]P $(2.5 \mu \mathrm{M})$ and ethanol $(25 \mathrm{mM})$ [8]. However, whether such a hampered metabolism could be responsible for the related cell death has not been tested yet. Based upon the fact that our group previously found that co-exposing healthy rat primary hepatocytes to ethanol and $\mathrm{B}[\mathrm{a}] \mathrm{P}$ induced an apoptosis dependent on metabolism of both chemicals [29], the 


\section{ACCEPTED MANUSCRIPT}

present study therefore aimed at evaluating the possible involvement of xenobiotic metabolism in the increased cell death detected in steatotic hepatocytes under co-exposure to these two chemicals. To do so, we decided to test the involvement of phase I metabolism of $\mathrm{B}[\mathrm{a}] \mathrm{P}$ and ethanol in the related cell death in steatotic hepatocytes of the WIF-B9 cell line. This cell line was chosen since a progression of steatosis towards a steatohepatitis-like stage was observed with $\mathrm{B}[\mathrm{a}] \mathrm{P}$ and ethanol even at very low concentrations (10 $\mathrm{nM}$ and $5 \mathrm{mM}$, respectively), which are close to those to which humans can be usually exposed [8]. Besides, it is known that depending on $\mathrm{B}[\mathrm{a}] \mathrm{P}$ concentration, different signaling pathways can be triggered [30,31].

In the present study, we demonstrated that the cell death induced by co-exposing steatotic WIF-B9 hepatocytes to $\mathrm{B}[\mathrm{a}] \mathrm{P}$ and ethanol resulted from a p53 activation triggered by a potentiated DNA damage. Furthermore, our results pointed to nitric oxide (NO) production as a possible important player in this process. First, it seemed to modify both $\mathrm{B}[\mathrm{a}] \mathrm{P}$ and ethanol metabolisms that thereafter might closely interplay via $\mathrm{AhR}$ and $\mathrm{ADH}$ to produce reactive oxygen species (ROS). Second, NO by reacting with superoxide anion, would form peroxynitrite with important consequences in terms of DNA damage and cell death. In total, our work suggests cooperative mechanistic interactions between $\mathrm{B}[\mathrm{a}] \mathrm{P}$ and ethanol, which would involve $\mathrm{AhR}, \mathrm{ADH}$ and $\mathrm{NO}$ as key players, to favor oxidative damages and hence hepatocyte death in a context of a prior steatosis. 


\section{ACCEPTED MANUSCRIPT}

\section{2-MATERIAL AND METHODS}

\subsection{Chemicals, antibodies and reagents}

Benzo[a]pyrene (purity: $\geq 96 \%$ ), chlorzoxazone (CZX), 1-Methyl-N-[2-methyl-4-[2-(2methylphenyl) diazenyl]phenyl-1H-pyrazole-5-carboxamide (CH-223191), 2-4-carboxyphenyl4,4,5,5-tetramethylimidazoline-1-oxyl-3-oxide (CPTIO), 4',6-Diamidine-2'-phenylindole dihydrochloride (Dapi), N-acetyl-Asp-Glu-Val-Asp-7-amido-4-methylcoumarin (Ac-DEVD-AMC), 7-ethoxyresorufin, Hoechst-33342, NG-Monomethyl-L-arginine acetate salt (L-NMMA), 4methylpyrazole (4-MP), $\beta$-nicotinamide adenine dinucleotide (NADH), $\alpha$-Naphthoflavone ( $\alpha \mathrm{NF})$, pifithrine- $\alpha$ (PFT), salicylamide, thiourea and $\alpha$-tocopherol (vitamin E) were all purchased from Sigma-Aldrich (Saint Quentin Fallavier, France). Ethanol (EtOH; purity: 99.97\%) used for cell treatment was obtained from Prolabo (Paris, France). N-benzyloxycarbonyl-Val-Ala-Asp(O-Me) fluoromethyl ketone (zVAD-FMK) was from Calbiochem (Millipore, Saint-Quentin Les Yvelines, France). NFkB inhibitor Bay 11-7082 was purchased from Promega (Charbonnières, France). Dihydroethidium (DHE) and Sytox ${ }^{\circledR}$ green were obtained from Invitrogen, (Cergy Pontoise, France). $\mathrm{Fe}(\mathrm{III}) 5,10,15,20$-tetrakis(4-sulfonatophenyl)porphyrinato chloride (FeTPPS) was from Santa Cruz Biotechnology (Heidelberg, Germany). $\left[{ }^{3} \mathrm{H}\right]$ thymidine was purchased from Amersham Biosciences (Buck, United Kingdom). 6-Hydroxy Chlorzoxazone (6-OH-CZX) and Chlorzoxazone O-Glucuronide (OCZX) were obtained from Toronto Research Chemicals (North York, Canada), and chlorzoxazone N-Glucuronide (NCZX) from Bertin Pharma (Montigny-le-Bretonneux, France).

Concerning western blotting and immunocytochemistry experiments, mouse monoclonal antiphospho-H2AX (Ser139) (05-636) and rabbit polyclonal anti-CYP2E1 (AB1252) antibodies were purchased from Merck Millipore (Molsheim, France); mouse monoclonal anti-HSC70 (sc-7298) and mouse monoclonal anti-p65 (sc-8008) antibodies were obtained from Santa Cruz Biotechnology (Heidelberg, Germany); rabbit polyclonal anti-CYP1A1 (Ab79819) and rabbit polyclonal anti-iNOS (Ab3523) antibodies were purchased from Abcam (Paris, France); mouse monoclonal anti-p53 (2524S) and rabbit monoclonal anti-phospho-p65 (Ser536) (3033) were purchased from Cell 


\section{ACCEPTED MANUSCRIPT}

Signalling Technology (Saint Quentin, France), while rabbit polyclonal anti-AhR (BML-SA550) and rabbit polyclonal anti-53BP1 (NB100-304) were obtained from Enzo life science (Villeurbanne, France) and Novus Biological (Abingdon, United Kingdom), respectively. The Alexa Fluor conjugates were acquired from Invitrogen (Cergy Pontoise, France), and secondary antibodies conjugated with horseradish peroxidase were from DAKO (Les Ulis, France).

Concerning the chemicals used for $\mathrm{B}[\mathrm{a}] \mathrm{P}$ metabolite and DNA adduct analyses, benzo[a]pyrene- $\mathrm{d}_{12}, 1$ - hydroxybenz[a]anthracene- ${ }^{13} \mathrm{C}_{6}, 1-, 2-, 3-, 4-, 5-, 6-, 7-$, 8-, 9-, 10-, $11-$ and 12OH-benzo[a]pyrene，4,5-di-OH-benzo[a]pyrene-trans，4,5-di-OH-benzo[a]pyrene-cis，9,10-di-OHbenzo[a]pyrene-trans, 7,8-di-OH-benzo[a]pyrene-cis and 7,8-di-OH-benzo[a]pyrene-trans, B[a]P-r-7,t8,t-9-tetrahydrotriol, $\quad$ B[a]P-r-7,t-8,c-9-tetrahydrotriol, $\quad( \pm)$-benzo[a]pyrene-r-7,t-8,t-9,c-10tetrahydrotetrol (B[a]PRTTC), ( \pm )-benzo[a]pyrene-r-7,t-8,t-9,t-10-tetrahydrotetrol (B[a]P-RTTT), ( \pm )benzo[a]pyrene-r-7,t-8,c-9,c-10-tetrahydrotetrol (B[a]P-RTCC), and ( \pm )-anti-r-7,t-8-dihydroxy-t-9,10epoxy-7,8,9,10-tetrahydrobenzo[a]pyrene-d8 [( \pm anti-B[a]PDE- $\left.\mathrm{d}_{8}\right]$ were obtained from MRI-Global (Kansas City, MO, United States). ( \pm ) Benzo[a]pyrene-r-7,t-8,c-9,t-10-tetrahydrotetrol (B[a]P-RTCT) was obtained from Toronto Research Chemicals (North York, Canada). The purity of almost all the compounds investigated was more than $98 \%$ and was taken into consideration for the preparation of the standard solutions. Thus, $\mathrm{B}[\mathrm{a}] \mathrm{P}$ standard, internal standards and standard stock solutions of $\mathrm{B}[\mathrm{a}] \mathrm{P}$ metabolites were prepared in acetonitrile at $10 \mathrm{mg} / \mathrm{l}$. Working solutions were prepared in acetonitrile by successive ten-fold dilutions at concentration ranging from $1000 \mathrm{mg} / \mathrm{l}$ to $10 \mathrm{mg} / \mathrm{l}$ and were stored at $-20^{\circ} \mathrm{C}$. Phree phospholipid removal columns were purchased from Phenomenex (Utrecht, the Netherlands). The derivatization reagent MTBSTFA (purity $97 \%$ or greater) containing $1 \%$ tertbutyldimethylchlorosilane, sulfatase and beta-glucuronidase from Helix pomatia juice were supplied by Sigma-Aldrich (Bornem, Belgium). Ultrapure water was produced by means of an AFS-8 system from Millipore (Brussels, Belgium). The derivatization agents N-methyl-N(trimethylsilyl)trifluoroacetamide (MSTFA: purity $96 \%$ or greater) and N-methyl-Ntertbutyldimethylsilyltrifluoroacetamide (MTBSTFA: purity $97 \%$ or greater) containing $1 \%$ tertbutyldimethylchlorosilane were obtained from Macherey-Nagel (Filterservice, Eupen, Belgium) and 


\section{ACCEPTED MANUSCRIPT}

Sigma-Aldrich (Diegem, Belgium), respectively. The quality "Dioxins, Pesti-S" was chosen for ethylacetate and cyclohexane, and the quality "ULC-MS" was selected for acetonitrile and water. All solvents were supplied by Biosolve (Dieuze, France).

\subsection{WIF-B9 cell culture and treatments}

WIF-B9 cell line was a generous gift from Dr Doris Cassio (UMR Inserm S757, Université Paris-Sud, Orsay, France). This hybrid hepatic cell line was obtained by fusion of Fao rat hepatoma cells and WI-38 human fibroblasts [32]. WIF-B9 cells were cultured in F-12 Ham medium with Coon's modification (Sigma-Aldrich, Saint Quentin Fallavier, France) containing 5\% fetal calf serum (Eurobio, Courtaboeuf, France), $0.22 \mathrm{~g} / \mathrm{L}$ sodium bicarbonate, $100 \mathrm{U} / \mathrm{mL}$ penicillin, $0.1 \mathrm{mg} / \mathrm{mL}$ streptomycin, $0.25 \mu \mathrm{g} / \mathrm{mL}$ amphotericin B, $2 \mu \mathrm{mM}$ glutamine, and supplemented with HAT $(10 \mu \mathrm{M}$ hypoxanthine, $40 \mathrm{nM}$ aminopterin, $1.6 \mu \mathrm{M}$ thymidine), and were incubated at $37{ }^{\circ} \mathrm{C}$ in an atmosphere constituted of $5 \% \mathrm{CO}_{2}$ and $95 \%$ air. Cells were seeded at $12.5 \times 10^{3}$ cells $/ \mathrm{cm}^{2}$ and were cultured for 7 days until obtaining approximately $80 \%$ of confluence, before any treatment. Prior steatosis was then induced by a 2-days treatment of cells with a culture medium containing a mixture of fatty acid / albumin complexes, as previously described [8]. Steatotic or non-steatotic cells were exposed to toxicants (10 $\mathrm{nM} \mathrm{B}$ [a]P with or without $5 \mathrm{mM}$ ethanol) or dimethyl sulfoxide for control cultures, for $3 \mathrm{~h}$ up to 5 days depending on experiments. Exposure protocol was given in Bucher et al. [8]. In case of treatment with inhibitors, cultures were pre-treated for $1 \mathrm{~h}$ prior to co-exposure with toxicants.

\subsection{Cell death and toxicity evaluation}

\subsubsection{Apoptosis and necrosis evaluation}

Cells were tested for both apoptotic and necrotic cell death by fluorescence microscopic observation after Hoechst/Sytox green staining. After toxicant exposure, cells were stained with $50 \mu \mathrm{g} / \mathrm{mL}$ Hoechst 33342 and $93.5 \mathrm{nM}$ Sytox green in the dark at $37^{\circ} \mathrm{C}$ for $30 \mathrm{~min}$. Apoptotic and necrotic cells were then 


\section{ACCEPTED MANUSCRIPT}

counted using a ZEISS Axio Scope A1 microscope. Cells with condensed and/or fragmented chromatin were counted as apoptotic and sytox green-stained cells were counted as necrotic cells. More than 300 cells were analyzed per condition.

\subsubsection{Measurement of caspases $3 / 7$ activity}

The caspase-3/7 activity assays were performed using Ac-DEVD-AMC tetrapeptide as fluorogenic substrate, as previously described [29].

\subsubsection{Measurement of intracellular ATP levels}

Intracellular ATP content was measured with the CellTiter-Glo ${ }^{\circledR}$ Luminescent Cell Viability assay (Promega, Charbonnières, France), according to the manufacturer's instructions, as previously described [8].

\subsubsection{Evaluation of mitochondrial ultrastructural changes}

Ultrastructural changes of mitochondria were visualized by transmission electron microscopy. After 5 days of toxicant exposure, cells were rinsed with $0.15 \mathrm{M} \mathrm{Na}$ cacodylate buffer, $\mathrm{pH} 7.4$ and fixed by drop-wise addition of glutaraldehyde $(2.5 \%)$ in cacodylate $0.15 \mathrm{M}$, for $1 \mathrm{~h}$. They were then washed with $0.15 \mathrm{M} \mathrm{Na}$ cacodylate buffer and post-fixed with $1.5 \%$ osmium tetroxide for $1 \mathrm{~h}$. Samples were next washed with cacodylate buffer and were dehydrated through a series of graded ethanol from 70 to $100 \%$. Samples were then infiltrated in a mixture of acetone-Eponate $(50 / 50)$ for $3 \mathrm{~h}$ and in pure Eponate for $16 \mathrm{~h}$. Finally, samples were embedded in DMP30-Eponate for $24 \mathrm{~h}$ at $60{ }^{\circ} \mathrm{C}$. Sections $(0.5 \mu \mathrm{m})$ were cut on a Leica UC7 microtome (Leica Microsystems, Wetzlar, Germany) and stained with toluidine blue. Ultrathin sections $(90 \mathrm{~nm})$ were obtained, mounted onto copper grids, and counterstained with 4\% uranyl acetate and Reynolds' lead citrate. Sample examination was performed with a JEOL 1400 transmission electron microscope operated at $120 \mathrm{kV}$.

\subsection{Immunofluorescence experiments}

\subsubsection{DNA damage analysis by $\gamma-H 2 A X$ and $53 B P 1$ immunostaining}




\section{ACCEPTED MANUSCRIPT}

DNA damage was assessed by analyzing the H2AX phosphorylation on Ser139 (called $\gamma$-H2AX) by immunocytochemistry, as previously described [33]. After 5 days of treatments, cells grown on coverslips were fixed in 4\% paraformaldehyde for 15 min, washed with PBS and then permeabilized in $0.5 \%$ Triton-X-100 for $10 \mathrm{~min}$. After blocking unspecific binding sites, cells were then incubated with 1:1000 diluted anti- $\gamma-\mathrm{H} 2 \mathrm{AX}$ antibody for $2 \mathrm{~h}$. In some experiments, in order to test the nature of DNA damage, cells were also co-incubated with anti-53BP1 antibody (1:3000 dilution) which allows detection of double-strand breaks (Supplementary Fig. S1A).

After washing in PBS, cells were next incubated for $2 \mathrm{~h}$ with secondary Alexa fluor FITC-and Texas Red-conjugated secondary antibodies. After a last washing, nuclei were stained with $300 \mathrm{nM}$ DAPI for 5 min. Slides were then viewed using an automated microscope Leica DMRXA2 (Leica Microsystems, Wetzlar, Germany) with a $63 \times$ fluorescence objective. Cells were counted as positive for DNA damage when the number of nuclear $\gamma-\mathrm{H} 2 \mathrm{AX}$ foci was $>5$. More than 100 cells were evaluated per condition of treatment. Example of negative and positive cells is shown in supplementary Fig. S1A.

\subsection{2.p53 immunostaining}

Same protocol as for $\gamma-\mathrm{H} 2 \mathrm{AX}$ immunostaining was performed for analysis of $\mathrm{p} 53$. The dilution of anti-p53 antibody applied for these experiments was 1:500.

\subsection{3. iNOS immunostaining}

After $48 \mathrm{~h}$ of treatment, cells were fixed in $4 \%$ paraformaldehyde for $15 \mathrm{~min}$, washed with PBS. Following blocking of unspecific binding sites, cells were then incubated with anti-iNOS antibody overnight (1:50 dilution) at $4^{\circ} \mathrm{C}$. After washing in PBS, cells were incubated for $2 \mathrm{~h}$ with secondary Alexa fluor FITC-conjugated secondary antibodies. After a further washing, nuclei were stained with $300 \mathrm{nM}$ DAPI for $5 \mathrm{~min}$. Slides were viewed using confocal fluorescence microscope LEICA DMI 6000 CS (Leica Microsystems, Wetzlar, Germany) with a 63× fluorescence objective. Quantification of green fluorescence (iNOS) was given relative to blue fluorescence (DAPI). 


\section{ACCEPTED MANUSCRIPT}

\subsection{Analysis of gene mRNA expression}

This analysis was realized as previously described [8]. Sequences of the rat primers presently tested are provided in supplementary Table S1. Note that a CT (Cycle Threshold) over 30 cycles was indicative of a low gene expression in WIF-B9 cells.

\subsection{Western blotting}

After 2 or 5 days of treatment, cells were harvested and sonicated on ice in RIPA buffer supplemented with protein inhibitors $(1 \mathrm{mM}$ orthovanadate, $1 \mathrm{mM}$ phenylmethylsulfonyl fluoride, 5 $\mu \mathrm{g} / \mathrm{ml}$ leupeptin, $0.1 \mu \mathrm{g} / \mathrm{ml}$ aprotinin, $0.5 \mathrm{mM}$ dithiothreitol), or a cocktail of protein inhibitors (Roche). After determination of protein concentration, 30 to $100 \mu \mathrm{g}$ of whole-cell lysates were heated for $5 \mathrm{~min}$ at $95^{\circ} \mathrm{C}$, loaded in a $4.5 \%$ stacking gel, and then separated by sodium dodecyl sulfatepolymerase gel electrophoresis (SDS-PAGE). Gels were then electroblotted onto nitrocellulose membranes (Millipore) overnight at $4{ }^{\circ} \mathrm{C}$. Membranes were next blocked with a Tris-buffered saline solution supplemented with $2 \%$ bovine serum albumin for $2 \mathrm{~h}$ and then hybridized with primary antibodies overnight at $4{ }^{\circ} \mathrm{C}$. Membranes were then incubated with appropriate horseradish peroxidase-conjugated secondary antibodies for $1 \mathrm{~h}$. Immunolabeled proteins were then visualized by chemiluminescence using the LAS-3000 analyzer (Fujifilm). Image processing was performed using Multi Gauge software (Fujifilm). For protein loading evaluation, a primary antibody against HSC70 was used.

\subsection{Measurement of cytochrome P450s' and ADH activities}

\subsubsection{CYP1 activity}

Ethoxyresorufin O-deethylase (EROD) assay, used to estimate the CYP1 activity, is based on the conversion of ethoxyresorufin into resorufin by CYP1 enzymes. Briefly, after 5 days of treatment, 


\section{ACCEPTED MANUSCRIPT}

cells were incubated in PBS supplemented with $1.5 \mathrm{mM}$ salicylamide (used to inhibit phase IIconjugating enzymes) and $5 \mu \mathrm{M}$ ethoxyresorufin. Fluorescence of resorufin ( $\lambda$ excitation at $544 \mathrm{~nm}$ and $\lambda$ emission at $584 \mathrm{~nm}$ ) was monitored for $30 \mathrm{~min}$ at $37^{\circ} \mathrm{C}$ using a microplate reader (EnSpire Multimode 2300 Plate Reader; Perkin Elmer, Waltham, United States). Readings were compared to a resorufin standard curve including blanks. EROD activity was expressed as pg resorufin per min and mg protein.

\subsubsection{CYP2E1 activity}

CYP2E1 activity is usually assessed by the measurement of the conversion of chlorzoxazone (CZX) to 6-hydroxychlorzoxazone (6-OH-CZX) in biological fluids and microsomes. However, as no 6-OH CZX was detected in WIF-B9 cells, CYP2E1 activity was determined by analysis of the formation of chlorzoxazone O-glucuronide (OCZX) by a high-performance liquid chromatography (HPLC) method [34]. Briefly, after 5 days of treatment, cells were washed in William's E medium without phenol red and then incubated with $500 \mu \mathrm{l}$ of $300 \mu \mathrm{M}$ chlorzoxazone $(\mathrm{CZX})$ for 6 hours at $37^{\circ} \mathrm{C}$. After centrifugation (14000 g, $10 \mathrm{~min}$ ) of culture media, $100 \mu \mathrm{l}$ of the supernatant were injected onto a HPLC chromatograph [Agilent 1260 Infinity (Agilent, Nantes, france)]. CZX and its metabolites were resolved by a binary gradient on a Zorbax Eclipse plus C18 reversed phasecolumn $(5 \mu \mathrm{m}, 4.6$ x 250 $\mathrm{mm})$ (Agilent, Nantes, France) equipped with a C18 pre-column insert $(2 \mu \mathrm{m}, 4.6 \times 12.5 \mathrm{~mm})$ (Zorbax reliance Cartridge guard, Agilent, Nantes, France) and set at $20{ }^{\circ} \mathrm{C}$. Mobile phases A and B were respectively constituted of trimethylamine in acetic acid $(0.1 \%)$ and acetonitrile. The total flow rate was $2.2 \mathrm{ml} / \mathrm{min}$. The solvent program was as follows: $98 \%$ mobile phase A from 0 to $3.5 \mathrm{~min}$, a step gradient to $35.5 \% \mathrm{~B}$ at $16 \mathrm{~min}, 90 \%$ mobile phase B maintained from 18.5 to $27 \mathrm{~min}$, followed by reequilibration with $98 \%$ mobile phase A from 28 to $35 \mathrm{~min}$. CZX and its metabolites were monitored at $287 \mathrm{~nm}$ with a variable wavelength UV detector. The retention times of OCZX, NCZX, 6-OH-CZX and CZX were approximately 8, 11.9, 12.4 and 17.8 mins, respectively. 6-OH-CZX was not detectable possibly because of a high activity of UGT which converts it to OCZX [34]. CYP2E1 enzymatic activity was thus considered to correspond to the rate of formed OCZX, and was expressed as $\mathrm{pmol} / \mathrm{min} / \mathrm{mg}$ protein. 


\section{ACCEPTED MANUSCRIPT}

\subsubsection{Alcohol dehydrogenase activity}

Alcohol dehydrogenase (ADH) activity was assessed by measurement of the reduced form of $\beta$ nicotinamide adenine dinucleotide $(\beta-\mathrm{NADH})$ stemming from ethanol oxidation in presence of the oxidized form $\beta$-NAD+. Briefly, after washing with PBS, cells were sonicated in $0.1 \mathrm{M}$ glycine buffer at $\mathrm{pH} 10$. The $1 \mathrm{ml}$ reaction mixture was constituted of $600 \mu \mathrm{l} \mathrm{pH} 10$ glycine buffer, $100 \mu$ l ethanol, $100 \mu \mathrm{l} \beta$-NAD $(5 \mathrm{mg} / \mathrm{ml})$ and $200 \mu \mathrm{l}$ cell lysate. Formation of $\beta$-NADH was monitored by measuring the absorbance at $340 \mathrm{~nm}$ for $30 \mathrm{~min}$ at $37^{\circ} \mathrm{C}$ using a microplate reader (EnSpire Multimode 2300 Plate Reader; Perkin Elmer, Waltham, United States). Specific ADH activity was expressed as units $/ \mathrm{min} / \mathrm{mg}$ protein, and the values were quoted relative to control cells.

\subsection{Analyses of $B[a] P$ metabolites and DNA adduct formation}

\subsubsection{Analyses of $B[a] P$ and its metabolites in culture medium}

Culture medium sample (400 $\mu$ l) was firstly homogenized with $10 \mu \mathrm{l}$ of glacial acetic acid (10\%) in order to reach a $\mathrm{pH}$ of 5.6 , then $20 \mu \mathrm{l}$ of the mixed internal standard solution $(0.1 \mathrm{mg} / \mathrm{l})$ were added. Enzymatic hydrolysis was performed for $2 \mathrm{~h}$ at $37^{\circ} \mathrm{C}$ using $20 \mu \mathrm{l}$ of sulfatase $(2.5$ units/ $\mu \mathrm{l})$ and $5 \mu \mathrm{l}$ of beta-glucuronidase (127 units/ $\mu \mathrm{l})$. The residue was applied onto a phree phospholipid removal column and $1200 \mu \mathrm{l}$ of acetonitrile with formic acid (1\%) were added before centrifugation at $5000 \mathrm{~g}$ for 10 mins. The eluate was divided into two equal parts to allow the separated analysis of B[a]P and its

metabolites. Concerning the analysis of $\mathrm{B}[\mathrm{a}] \mathrm{P}, 50 \mu \mathrm{l}$ of pure water were added before the evaporation under a nitrogen stream at $37^{\circ} \mathrm{C}$ to avoid dryness. Then a Liquid-Liquid Extraction (LLE) was carried out twice with water-cyclohexane-ethyl acetate $(50: 25: 25 ; \mathrm{v} / \mathrm{v} / \mathrm{v})$. The upper layer containing $\mathrm{B}[\mathrm{a}] \mathrm{P}$ was collected and dried until $25 \mu \mathrm{l}$. Pertaining to the analysis of metabolites, the residue was again divided in two equivalent parts and dried under a nitrogen flow at $37{ }^{\circ} \mathrm{C}$. Derivatization of $\mathrm{OH}-\mathrm{PAHs}$ was conducted by adding with $25 \mu 1$ of MTBSTFA to the extract whereas for $25 \mu 1$ of MSTFA were added to the second extract for the derivatization of di-OH-B[a]P, tri-OH-B[a]P and tetra-OH-B $[\mathrm{a}] \mathrm{P}$. 


\section{ACCEPTED MANUSCRIPT}

The latter steps were completed after $30 \mathrm{~min}$ at $60^{\circ} \mathrm{C}$. One $\mu 1$ of each final extract was then injected into the GC-MS/MS system. Analyses were carried out with an Agilent 7890A gas chromatograph equipped with a HP-5MS capillary column (30 m, $0.25 \mathrm{~mm}$ i.d., $0.25 \mathrm{~mm}$ film thickness), coupled with an Agilent 7000B triple quadrupole mass spectrometer operating in electron impact ionization mode and an Agilent CTC PAL autosampler. Details of analytical conditions used for chromatography and MS/MS detection were previously described [35,36]. Calibration curves were performed using culture medium specimens supplemented with increased concentration levels of $\mathrm{B}[\mathrm{a}] \mathrm{P}$ and of their metabolites from 0.01 to $10 \mathrm{ng} / \mathrm{ml}$ of culture medium. Limits of quantification (LOQs) were evaluated at $0.079 \mathrm{pmol} / \mathrm{ml}$ of culture media for $\mathrm{B}[\mathrm{a}] \mathrm{P}$, ranged from 0.19 to $0.79 \mathrm{pmol} / \mathrm{ml}$ for monohydroxylated- and evaluated at $0.07 \mathrm{pmol} / \mathrm{ml}$ for dihydroxylated forms of $\mathrm{B}[\mathrm{a}] \mathrm{P}$.

\subsubsection{DNA adduct measurements}

Tetrahydroxylated-benzo[a]pyrene (tetra-OH-B[a]P) resulting from the hydrolysis of their respective diol-epoxide precursors, involved in DNA-adduct formation, have been analyzed in DNA samples using a previously published method [37].

\subsection{Detection of oxidative stress}

\subsubsection{Determination of ROS production}

Intracellular ROS production was assessed using dihydroethidium (DHE), a fluorescent probe sensitive to superoxide anion. DHE has been shown to be oxidized specifically by superoxide to form 2-OH-ethidium (2-OH-E ${ }^{+}$, but also unspecifically to form ethidium $\left(\mathrm{E}^{+}\right)$; both products are fluorescent with a significant spectrum overlap when excitation light in the range of $450-500 \mathrm{~nm}$ is used $[38,39]$. Even though the applicability was not proven by a HPLC-based method in our model of WIF-B9 cells, we used the difference in the excitation spectra in the $350-450 \mathrm{~nm}$ range which was found to be more selective for 2-OH-E+ in human aortic endothelial cells [40]. Briefly, after 5 days of treatment, cells were exposed to DHE $(25 \mu \mathrm{M})$ in HEPES buffer for $1 \mathrm{~h}$. Then, fluorescence of 2-OH-E+ was recorded 


\section{ACCEPTED MANUSCRIPT}

by a SpectraMax Gemini spectrofluorimeter (Molecular Devices, Sunnyvale, United States) (Ex 396 $\mathrm{nm} / \mathrm{Em} 580 \mathrm{~nm})$. Results were given as fluorescence arbitrary units (AU)/mg protein.

\subsubsection{Evaluation of lipid peroxidation}

Lipid peroxidation was assessed in culture media by measuring free malondialdehyde (MDA), a secondary end-product of lipid hydroperoxide decomposition. Briefly, after 5 days of treatment, culture media were collected and filtered through a 1000-Da ultrafiltration membrane (Millipore, Saint-Quentin-les-Yvelines, France) in a 10-ml Amicon cell (Amicon, United States) pressurized at 3 bars with nitrogen gas. Two hundred fifty microliters of the filtrate were then analyzed by size exclusion chromatography, as previously described [41]. The HPLC system [Agilent 1260 Infinity (Agilent, Nantes, France)] was equipped with a TSK-gel G1000 PW $(7.5 \mathrm{~mm}$ x $30 \mathrm{~cm})$ size exclusion column (TOSOH Bioscience, Tokyo, Japan). The eluant was composed of $0.1 \mathrm{M}$ disodium phosphate buffer, $\mathrm{pH} 8$ at a flow rate of $1 \mathrm{ml} / \mathrm{min}$. The elution was monitored by a UV detector set at $267 \mathrm{~nm}$.

\subsubsection{Measurement of $N O$ production}

NO production was assessed by measuring dinitrosyl iron complex (DNIC) in cells. DNIC, corresponding to the binding of NO to iron-containing molecules, were directly detected in intact cells using electron paramagnetic resonance (EPR), according to a method previously described [42]. Briefly, after 5 days of treatment, culture media were removed and cells were scraped, washed, resuspended in a buffer containing $50 \mathrm{mmol} / \mathrm{l}$ HEPES and $250 \mathrm{mmol} / \mathrm{l}$ sucrose at $\mathrm{pH} 7.5$. Then, cells were transferred to quartz EPR tubes and frozen. EPR examination was performed at $100 \mathrm{~K}$ using a Bruker Elexsys E500 spectrometer with 10-G modulation amplitude, 100-kHz modulation frequency, 9.41-GHz frequency, and 20-mW microwave power. Intensity of DNIC spectra was estimated by double integration of both lines and expressed as arbitrary units (AU) normalized to total protein concentration.

\subsection{Statistical analysis}




\section{ACCEPTED MANUSCRIPT}

All values were presented as means \pm SD from at least three independent experiments. Statistical analyses were performed using either two-way analysis of variance (ANOVA) followed by a post hoc Bonferroni test, or one-way ANOVA followed by a Student-Newman-Keuls post-test. Significance was accepted at $\mathrm{p}<0.05$. All statistical analyses were performed using GraphPad Prism5 software (San Diego, United States). 


\section{3-RESULTS}

\subsection{Role for effector caspases and activation of the tumor suppressor p53 protein related to} DNA damage in the cell death induced by co-exposing steatotic WIF-B9 hepatocytes to $B[a] P$ and ethanol.

We previously demonstrated that co-exposure of pre-steatotic WIF-B9 to $\mathrm{B}[\mathrm{a}] \mathrm{P}(10 \mathrm{nM})$ and ethanol $(5 \mathrm{mM})$ for 5 days led to a significant increase in the number of cells with condensed/fragmented chromatin along with a decrease in intracellular ATP [8]. In order to further characterize the type of cell death involved, and as caspase activation was previously shown to be involved in the toxicity of $\mathrm{B}[\mathrm{a}] \mathrm{P} / \mathrm{ethanol}$ co-exposure detected in healthy primary hepatocytes [29], a role for effector caspases was tested using the broad caspase inhibitor zVAD $(10 \mu \mathrm{M})$. As shown in Fig. 1A, following zVAD treatment, a significant decrease in the number of cells with condensed/fragmented chromatin was observed in the presence of $\mathrm{B}[\mathrm{a}] \mathrm{P} / \mathrm{ethanol}$ co-exposure. Note that the cell death induced by $\mathrm{B}[\mathrm{a}] \mathrm{P}$ alone was also fully inhibited. Furthermore, an increase in caspase activity was detected upon co-exposure, which was significantly higher compared to B[a]P alone (Fig. 1B). It is important to stress that neither increased cell necrosis (Supplementary Fig. S1B) nor changes in cell proliferation (Supplementary Fig. S1C) were observed in steatotic cells whatever the treatment applied.

As DNA damage is usually related to $\mathrm{B}[\mathrm{a}] \mathrm{P}$-induced cell death $[43,44]$, we then looked for the appearance of such a phenomenon, by analyzing the phosphorylation of H2AX on Ser139, an H2A histone variant (called $\gamma$-H2AX once phosphorylated; [33]). As shown in Fig. 1C, a marked increase in DNA damage was observed upon co-exposure to $\mathrm{B}[\mathrm{a}] \mathrm{P} / \mathrm{ethanol}$, especially in steatotic cells. Activation of the tumor suppressor protein p53 is generally associated with $\mathrm{B}[\mathrm{a}] \mathrm{P}$-induced DNA damage and subsequent cell death $[44,45]$. Therefore, the effect of pifithrin- $\alpha$ (PFT; $10 \mu \mathrm{M})$, known to inhibit p53 activation, was next tested. As illustrated in Fig. 1D, PFT significantly inhibited the number of apoptotic cells induced by $\mathrm{B}[\mathrm{a}] \mathrm{P} / \mathrm{ethanol}$ co-exposure as well as following $\mathrm{B}[\mathrm{a}] \mathrm{P}$ treatment alone in presence of steatosis. Note that no effect of PFT on CYP1 activity was presently detected 


\section{ACCEPTED MANUSCRIPT}

(data not shown). Whereas no marked increase was observed in total p53 protein content upon toxicant co-exposure or $\mathrm{B}[\mathrm{a}] \mathrm{P}$ alone as compared to control steatotic cells (Supplementary Fig. S1D), a clear nuclear translocation of p53 occurred upon both these treatments (Fig. 1E). This translocation of p53 to nucleus upon co-exposure was paralleled by an induction by $\sim 50 \%$ of the $p 21$ mRNA expression (Fig. 1F), a well-known gene target of p53 [33]. It is also worth emphasizing that co-exposure induced marked changes of mitochondria morphology, with cristae loss and swelling of the organelles (Supplementary Fig. S2A), without any change in the free fatty acid content of the cells (Supplementary Fig. S2B). This thus ruled out lipotoxicity as a possible cause of this co-exposureinduced cell death.

Altogether, these results demonstrated that the cell death induced by co-exposing steatotic WIF-B9 hepatocytes to B[a]P and ethanol was partly a caspase-dependent apoptosis, resulting from p53 activation triggered by marked DNA damage.

\subsection{Involvement of B[a]P metabolism in the cell death induced by co-exposing steatotic WIF-B9 hepatocytes to $B[a] P$ and ethanol.}

In order to test the possible involvement of CYP1-dependent $\mathrm{B}[\mathrm{a}] \mathrm{P}$ metabolism, we used a known inhibitor of these CYPs, i.e. $\alpha$-naphthoflavone $(\alpha \mathrm{NF} ; 10 \mu \mathrm{M})$. Our data clearly showed that cell treatment for 5 days with $\alpha \mathrm{NF}$ prevented the cell death induced by co-exposure to $\mathrm{B}[\mathrm{a}] \mathrm{P}$ and ethanol of steatotic cells. Indeed, we found that the increase in the number of cells with condensed/fragmented chromatin (Fig. 2A) and the decrease in intracellular ATP (Fig. 2B) upon co-exposure, were both significantly prevented when $\alpha \mathrm{NF}$ was present. The toxic effects of $\mathrm{B}[\mathrm{a}] \mathrm{P}$ alone were also inhibited (Fig. 2A, B). Furthermore, we observed that DNA damage, as evaluated by $\gamma \mathrm{H} 2 \mathrm{Ax}$ staining, induced by toxicant co-exposure or B[a]P alone, was fully blocked by $\alpha \mathrm{NF}$ (Fig. 2C). These results therefore pointed out a possible role for $\mathrm{B}[\mathrm{a}] \mathrm{P}$ metabolism, possibly via $\mathrm{CYP} 1$, in the toxic effects of $\mathrm{B}[\mathrm{a}] \mathrm{P} / \mathrm{ethanol}$ co-exposure or $\mathrm{B}[\mathrm{a}] \mathrm{P}$ alone under steatotic conditions. 


\section{ACCEPTED MANUSCRIPT}

The next set of experiments was thus carried out in order to thoroughly look at $\mathrm{B}[\mathrm{a}] \mathrm{P}$ metabolism. As no difference was detected regarding CYP1B1 expression (and so for the expression of both CYP3A1 and epoxide hydrolases EPHX1 and EPHX2) between steatosis and non-steatosis conditions (Supplementary Fig. S3), and due to the fact that WIF-B9 cells constitutively express CYP1A1 [46] which plays an important role in B[a]P metabolism [44], we decided to focus on the expression of this CYP. Data in Fig. 2D evidenced an increase in this CYP mRNA expression upon both $\mathrm{B}[\mathrm{a}] \mathrm{P} / \mathrm{ethanol}$ co-exposure as well as $\mathrm{B}[\mathrm{a}] \mathrm{P}$ treatment alone, notably in steatotic cells. However, no difference was observed between both treatments. Furthermore, from the western blotting experiments, it was clear that no change in CYP1A1 protein level occurred upon toxicant co-exposure (Fig. 2E). With regard to the activity of CYP1 enzymes, analysis of EROD activity at 5 days showed a significant increase in EROD activity upon both $\mathrm{B}[\mathrm{a}] \mathrm{P}$ alone and $\mathrm{B}[\mathrm{a}] \mathrm{P} / \mathrm{ethanol}$ co-exposure in nonsteatotic cells, with no difference between both treatments (Fig. 2F). However, in presence of steatosis, EROD activity was significantly decreased upon both treatments compared to non-steatotic counterparts. A similar trend was also observed following $48 \mathrm{~h}$ of treatments, although less marked for co-exposure (Supplementary Fig. S4A). As expected, $\alpha$ NF inhibited EROD activity detected in both non-steatotic and steatotic cells at 5 days of treatment (Supplementary Fig. S4B).

As steatosis hampered the activity of CYP1 enzyme upon toxicant co-exposure and $\mathrm{B}[\mathrm{a}] \mathrm{P}$ alone, we next studied metabolism of $\mathrm{B}[\mathrm{a}] \mathrm{P}$ under our experimental conditions. A gas chromatography tandem mass-spectrometry method dedicated to the analysis of $\mathrm{B}[\mathrm{a}] \mathrm{P}$ and its metabolites (both hydroxy and dihydroxy) was therefore applied to the culture media coming from cells exposed to all test conditions at 5 days (see Supplementary Fig. S5 and supplementary Table S2 for detailed results). As shown in supplementary Fig. S5A, it appeared that the amount of $\mathrm{B}[\mathrm{a}] \mathrm{P}$ remaining in media was higher in presence of steatosis, which would fit well with the decrease of CYP1 activity. Fig. 3 quotes the proportion of $\mathrm{B}[\mathrm{a}] \mathrm{P}$ relatively to total hydroxy- and total dihydroxy-metabolites of $\mathrm{B}[\mathrm{a}] \mathrm{P}$ detected for each treatment. Data from this figure confirmed that steatosis reduced B[a]P metabolism with a greater proportion of $\mathrm{B}[\mathrm{a}] \mathrm{P}$ detected $(\geq 30 \%)$ in steatotic cells, as compared to non-steatotic counterparts treated by $\mathrm{B}[\mathrm{a}] \mathrm{P}$ alone $(11 \%)$ or in combination with ethanol $(17 \%)$. Another interesting 


\section{ACCEPTED MANUSCRIPT}

observation is the fact that the relative proportion of diOH-metabolites upon $\mathrm{B}[\mathrm{a}] \mathrm{P}$ alone or $\mathrm{B}[\mathrm{a}] \mathrm{P} / \mathrm{ethanol}$ co-exposure was markedly reduced in steatotic compared to non-steatotic counterparts (Fig. 3). Altogether, this thus evidenced a change in $\mathrm{B}[\mathrm{a}] \mathrm{P}$ metabolism towards less production of diol metabolites of B[a]P upon steatosis. Note that in media collected from B[a]P-treated steatotic cells coexposed or not with ethanol, the concentration of 7-8-diOH-B[a]P-trans, the precursor of $\mathrm{B}[\mathrm{a}] \mathrm{P}-\mathrm{diol}-$ epoxide, was barely detected (Supplementary Table S2B), in line with the absence of detected DNAadducts regardless of the conditions of exposure (data not shown).

\subsection{Involvement of ethanol metabolism in the cell death induced by co-exposing steatotic WIF-} B9 hepatocytes to $\mathrm{B}[\mathrm{a}] \mathrm{P}$ and ethanol.

The next step was to test the involvement of ethanol metabolism in the toxicity induced by coexposure in steatotic cells. To do so, cells were co-treated with 4-methyl pyrazole (4-MP; $500 \mu \mathrm{M})$, a known inhibitor of both CYP2E1 and alcohol dehydrogenase (ADH; [47, 48]). As shown in Fig. 4A, 4-MP significantly inhibited the cell death induced by $\mathrm{B}[\mathrm{a}] \mathrm{P} / \mathrm{ethanol}$ co-exposure in steatotic cells. As ethanol metabolism was previously reported to induce DNA damage thereby triggering p53 activation [49], 4-MP was also tested towards co-exposure-induced DNA damage in steatotic cells. It was clear from Fig. 4B that the percentage of $\gamma \mathrm{H} 2 \mathrm{AX}$-positive cells was significantly reduced upon 4-MP treatment, therefore highlighting a role for ethanol metabolism in the DNA damage induced by coexposure under steatotic conditions.

We next analyzed the expression and activity of CYP2E1 following 5 days of co-exposure to $\mathrm{B}[\mathrm{a}] \mathrm{P}$ and ethanol, based upon the fact that this CYP was reported to be increased in liver steatosis, although this point is still a matter of debate $[23,50]$. Our data clearly indicated that neither mRNA expression nor protein level was altered under co-exposure of steatotic cells (Supplementary Fig. S6A and B); note also that no change in Cyp2el mRNA expression was observed following $48 \mathrm{~h}$ of treatment (Supplementary Fig. S6C). Regarding the activity of this CYP, a decrease was rather observed in steatotic cells, whatever the condition tested (Fig. 4C). As 4-MP is also known to inhibit 


\section{ACCEPTED MANUSCRIPT}

$\mathrm{ADH}$, the major enzyme system for metabolizing alcohol especially at low concentrations $[51,52]$, activity of this enzyme was next analyzed (Fig. 4D); this time, the activity was measured following only $3 \mathrm{~h}$ of treatment since it is known that chronic alcohol consumption does not result in increased ADH activity [51]. Our data showed first that the ADH activity was markedly potentiated by coexposure to both $\mathrm{B}[\mathrm{a}] \mathrm{P}$ and ethanol of steatotic cells, whereas no effect of $\mathrm{B}[\mathrm{a}] \mathrm{P}$ or ethanol alone was detected (Fig. 4D). As AhR (aryl hydrocarbon receptor) has been previously shown to play a role in the regulation of liver ADH expression [53] and based upon the fact that $\alpha \mathrm{NF}$, a known antagonist of AhR in addition to be a CYP1 inhibitor, prevented the cell death induced by co-exposure in steatotic cells (Fig. 2A), we decided to test a possible role for this B[a]P-activated receptor [44]. Fig. 4E showed that co-treatment with $\mathrm{CH}-223191(\mathrm{CH} ; 3 \mu \mathrm{M})$, an AhR specific antagonist, fully inhibited the increase in $\mathrm{ADH}$ activity elicited by co-exposing steatotic cells to both $\mathrm{B}[\mathrm{a}] \mathrm{P}$ and ethanol for $3 \mathrm{~h}$. Note that $\mathrm{CH}$ was also found to prevent the related cell death as well as that induced by $\mathrm{B}[\mathrm{a}] \mathrm{P}$ alone (Fig. 4F). In order to test whether the increase of ADH activity could be linked to an increase in mRNA expression, we looked at different $\mathrm{ADH}$ isoforms known to be expressed in rat liver, that is, $\mathrm{ADH} 1,4$, 5 and 7 [54]. A slight increase in mRNA expression, though not significant, was observed upon coexposure to $\mathrm{B}[\mathrm{a}] \mathrm{P}$ and ethanol of steatotic cells at $3 \mathrm{~h}$ especially regarding $A D H 7$; however, due to large variability in our experiments, it was difficult to conclude about the effects of CH-223191 (Supplementary Fig. S7A and B). Regarding aldehyde dehydrogenase (ALDH) expression, note that, although some changes in ALDH3 expression occurred with a trend towards a decrease upon coexposure or $\mathrm{B}[\mathrm{a}] \mathrm{P}$ alone, the expression of this enzyme would be low in WIF-B9 cells (Supplementary Fig. S7C).

Altogether, these results therefore pointed to a role for ethanol metabolism, via an AhRdependent $\mathrm{ADH}$ activation, in the toxic effects of the co-exposure to $\mathrm{B}[\mathrm{a}] \mathrm{P} / \mathrm{ethanol}$ under steatotic conditions. 


\section{ACCEPTED MANUSCRIPT}

\subsection{Involvement of oxidative stress in the cell death induced by co-exposing steatotic WIF-B9 hepatocytes to $B[a] P$ and ethanol.}

In order to get further insight into the intracellular mechanisms involved in the toxic effects of $\mathrm{B}[\mathrm{a}] \mathrm{P} / \mathrm{ethanol}$ co-exposure in steatotic hepatocytes, we tested a possible role for oxidative stress. Indeed, this phenomenon is well recognized as a "second hit" for the pathological progression of NAFLD (see eg. $[55,56]$ for recent reviews). Besides, ethanol and $\mathrm{B}[\mathrm{a}] \mathrm{P}$ metabolisms are known to induce oxidative stress [44,57-59]. Using co-treatment with thiourea $(6.25 \mathrm{mM}$; a scavenger of hydroxyl radicals, superoxide anion and hydrogen peroxide $[60,61])$, we first found that cell death (Fig. 5A) induced by co-exposing steatotic cells to $\mathrm{B}[\mathrm{a}] \mathrm{P}$ and ethanol was significantly inhibited, thus suggesting a role for oxidative stress in this process; note that the effects of $\mathrm{B}[\mathrm{a}] \mathrm{P}$ alone were also prevented. In order to evidence the trigger of oxidative stress, oxidative damages were next searched. This was performed by measuring the production of malondialdehyde (MDA), a main lipid peroxidation product. As shown in Fig. 5B, a marked increase in MDA content was detected upon coexposure compared to control under steatotic conditions; an increase, although less important, was also detected upon $\mathrm{B}[\mathrm{a}] \mathrm{P}$ alone. This increase upon co-exposure was inhibited by both $\alpha \mathrm{NF}$ and 4-MP (Supplementary Fig. S8). It is worth noting that steatosis per se already led to a significant rise in MDA content when compared to control non-steatotic cells (Fig. 5B). In addition, using the cotreatment with thiourea, the DNA damage induced by co-exposing steatotic cells to $\mathrm{B}[\mathrm{a}] \mathrm{P}$ and ethanol was inhibited, thus suggesting DNA oxidation (Fig. 5C). Using vitamin E (100 $\mu \mathrm{M})$, we found that lipid peroxidation could be partly involved in the toxic effects of co-exposure although these effects were less pronounced compared to thiourea (Supplementary Fig. S9). In order to elucidate the trigger mechanism of such an oxidative stress, we then decided to look for superoxide anion $\left(\mathrm{O}_{2}{ }^{-}\right)$production, since mitochondria were found to be markedly injured (Supplementary Fig. S2A). However, by using the fluorescent probe DHE, we were unable to detect any significant change of the fluorescence of 2hydroxyethidium (Fig. 5D) in steatotic cells co-exposed to $\mathrm{B}[\mathrm{a}] \mathrm{P}$ and ethanol compared to other treatment conditions. 
These results therefore demonstrated a role for oxidative stress in the cell death induced by coexposing steatotic cells to $\mathrm{B}[\mathrm{a}] \mathrm{P}$ and ethanol.

\subsection{Role for nitric oxide in the cell death induced by co-exposing steatotic WIF-B9 hepatocytes to $\mathrm{B}[\mathrm{a}] \mathrm{P}$ and ethanol.}

Due to the fact that no significant superoxide anion production could be detected upon coexposure (Fig. 5D) despite clear alterations of mitochondria (Supplementary Fig. S2A) and involvement of oxidative stress (Fig. 5A, C) in the related toxic effects, we then hypothesized that peroxynitrite anion might have been generated under our conditions. Indeed, it is well known that NO can very rapidly react with $\mathrm{O}_{2}^{-{ }^{-}}$to yield peroxynitrite $\left(\mathrm{ONOO}^{-}\right)$, a highly reactive oxidant species with important consequences in terms of cytotoxicity and pathophysiology $[62,63]$. This could explain a lesser availability of $\mathrm{O}_{2}{ }^{-}$for its detection by DHE. Our first set of experiments was performed in order to test whether an increase in NO production could occur under our experimental conditions. As shown in Fig. 6A, a potentiation of this production was detected only upon co-exposure to B[a]P and ethanol in steatotic cells following 5 days of treatment compared to other treatments. Note that steatosis per se induced a significant increase in NO production compared to non-steatotic cells. To evaluate a possible role for NO in the toxicity of co-exposure, cells were then co-treated with the NO scavenger carboxy-PTIO (CPTIO; $25 \mu \mathrm{M}$ ). As illustrated in Fig. 6B, this molecule fully inhibited the cell death induced by $\mathrm{B}[\mathrm{a}] \mathrm{P} / \mathrm{ethanol}$ co-exposure in steatotic cells; an inhibition was also observed when considering effects of $\mathrm{B}[\mathrm{a}] \mathrm{P}$ alone. As NO has been involved in DNA damage [64], CPTIO was also tested versus this parameter. We found that when CPTIO was present, DNA damage was markedly inhibited for both toxicant co-exposure and B[a]P alone (Fig. 6C). As NO can favor lipid peroxidation, CPTIO was also tested towards MDA production. As shown in Supplementary Fig. S8, the presence of CPTIO fully prevented such a production. Altogether, these results pointed to NO as a key player in the toxic effects of $\mathrm{B}[\mathrm{a}] \mathrm{P} / \mathrm{ethanol}$ co-exposure in steatotic cells. 


\section{ACCEPTED MANUSCRIPT}

The following set of experiments was performed in order to get further insight into a possible role for peroxynitrite anion in the cell death induced by $\mathrm{B}[\mathrm{a}] \mathrm{P} / \mathrm{ethanol}$ co-exposure of steatotic cells. To do so, the metalloporphyrin catalyst FeTPPS, which catalyzes peroxynitrite decomposition [65], was then tested. Our data first showed a significant inhibition of the cell death induced by either toxicant co-exposure or B[a]P alone in the presence of FeTPPS $(2.5 \mu \mathrm{M})$ under steatotic conditions (Fig. 6D). Besides, as peroxynitrite is known to induce DNA damage [66], FeTPPS was also tested towards this parameter. As shown in Fig. 6E, this catalyst fully prevented this damage induced by $\mathrm{B}[\mathrm{a}] \mathrm{P} / \mathrm{ethanol}$ co-exposure or $\mathrm{B}[\mathrm{a}] \mathrm{P}$ alone. Thus, peroxynitrite appeared to play an important role in the potentiation of the cell death induced by $\mathrm{B}[\mathrm{a}] \mathrm{P} / \mathrm{ethanol}$ co-exposure under steatotic conditions.

Then, another issue about the key role of $\mathrm{NO}$ in the cytotoxicity of $\mathrm{B}[\mathrm{a}] \mathrm{P} / \mathrm{ethanol}$ co-exposure in steatotic cells was addressed concerning the reduction of CYP1 activity (Fig. 2F), leading to a decrease in $\mathrm{B}[\mathrm{a}] \mathrm{P}$ metabolism (Fig.3; note that a change in $\mathrm{B}[\mathrm{a}] \mathrm{P}$ partitioning due to the presence of lipid droplets $[67,68]$ cannot as yet be ruled out with regard to this reduced metabolism). Indeed it is known that NO is capable of binding the heme of cytochrome P450s, thereby leading to their inhibition [62], thus suggesting a possible role for NO in the reduced activity in our model. Using CPTIO, we found a significant increase in EROD activity in steatotic cells, with a marked effect upon either $\mathrm{B}[\mathrm{a}] \mathrm{P} / \mathrm{ethanol}$ co-exposure or $\mathrm{B}[\mathrm{a}] \mathrm{P}$ treatment alone; a similar activation was then observed upon these treatments between steatotic and non-steatotic cells (Supplementary Fig. S10A). Interestingly, an increase in CYP2E1 activity in steatotic cells was also observed in presence of CPTIO, whatever the test condition (Supplementary Fig. S10B).

\subsection{Role for the induction of iNOS expression via AhR and NFkB activation in NO production.}

In an attempt to identify the origin of $\mathrm{NO}$, the activation of the inducible form of the nitric oxide synthase (iNOS) was analyzed. To do so, the induction of this enzyme was studied by immunofluorescence using a primary antibody specifically targeting the iNOS and a secondary fluorescent antibody. As shown in Fig. 7A and B, a marked induction of iNOS was observed upon co- 


\section{ACCEPTED MANUSCRIPT}

exposing steatotic cells to $\mathrm{B}[\mathrm{a}] \mathrm{P}$ and ethanol for $48 \mathrm{~h}$, as visualized by the increase of the green fluorescence in the cytoplasm compared to control steatotic cells. As iNOS has been previously suggested to be regulated by $\mathrm{AhR}$ notably upon $\mathrm{B}[\mathrm{a}] \mathrm{P}[69]$ as well as by $\mathrm{NF \kappa B}$ [70], a possible role

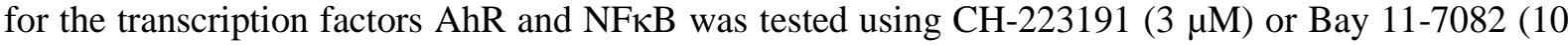
$\mu \mathrm{M})$, respectively. Our data showed that in presence of either inhibitor, activation of iNOS was significantly prevented in steatotic cells co-exposed to B[a]P and ethanol (Fig. 7A and C). We also found that Bay 11-7082 also markedly reduced the related toxicity (Supplementary Fig. S11A). Using thiourea $(6.25 \mathrm{mM})$, we also found that ROS were involved in iNOS induction (Fig. 7A and C). Whereas AhR activation was validated by the fact that $\mathrm{CH}-223191$ inhibited EROD activity under our experimental conditions (Supplementary Fig. S4D), we wanted to confirm activation of the NFkB pathway. As shown in Supplementary Fig. S11B, co-exposure to B[a]P and ethanol did induce a phosphorylation of the p65 subunit of NFkB in steatotic hepatocytes following $24 \mathrm{~h}$ of treatment, and this was associated with an increase of the intercellular adhesion molecule-1 (Icam-1) mRNA expression at 48h (Supplementary Fig. S11C), another known target of NFkB [71]. Altogether, the data showed NFKB activation. Having demonstrated an induction of iNOS under our experimental conditions, we then wanted to test its role in cell death induced by $\mathrm{B}[\mathrm{a}] \mathrm{P} / \mathrm{ethanol}$ co-exposure by using a specific inhibitor of NOS, that is, L-NMMA. We found that the cell death induced by the coexposure in the presence of L-NMMA $(500 \mu \mathrm{M})$ was significantly reduced (Fig. 7D) even though the effect appeared to be less marked than with CPTIO. Note that the B[a]P toxic effect was also inhibited by L-NMMA. Taken together, these data thus suggested that an AhR- and NFkB-dependent iNOS activation might be partly responsible for the cytotoxicity of $\mathrm{B}[\mathrm{a}] \mathrm{P} / \mathrm{ethanol}$ co-exposure in steatotic cells. 


\section{ACCEPTED MANUSCRIPT}

\section{4-DISCUSSION}

With the epidemics of obesity, NAFLD is becoming the most common chronic liver disease, notably in Western countries. NAFLD at the stage of simple steatosis can progress to more severe stages such as non-alcoholic steatohepatitis (NASH), notably upon exposure to environmental pollutants or to alcohol [1]. These factors are capable of interacting together to favor cell death and inflammation, that is NASH, as we previously demonstrated, both in vitro and in vivo, in the case of co-exposure of prior steatotic hepatocytes to both the carcinogenic pollutant $\mathrm{B}[\mathrm{a}] \mathrm{P}$ and ethanol [8]. Here we report for the first time in steatotic hepatocytes, that the cell death induced by such a coexposure might involve cooperative mechanistic interactions between the two xenobiotics, notably via AhR and NO, with consequences in terms of oxidative damages, notably induced by peroxynitrite.

Regarding activation of $\mathrm{p} 53, \mathrm{~B}[\mathrm{a}] \mathrm{P}$ is known to favor such a signaling event following DNA damage, notably resulting from the formation of DNA adducts after metabolism of this pollutant into BPDE, a well-recognized carcinogenic metabolite (see eg. [44] for review). Therefore, we were not surprised to evidence a significant DNA damage following co-exposure to $\mathrm{B}[\mathrm{a}] \mathrm{P}$ and ethanol. However, at first glance, what was puzzling was the fact that (i)-CYP1 activity was decreased upon steatosis, and (ii)-analysis of $\mathrm{B}[\mathrm{a}] \mathrm{P}$ metabolites clearly showed that metabolism of this xenobiotic in steatotic cells co-exposed to ethanol was significantly reduced. Regarding this latter point, it is worth emphasizing that upon steatosis, $\mathrm{B}[\mathrm{a}] \mathrm{P}$ metabolism mainly led to the production of monohydroxy metabolites (especially 3-OH-B[a]P) i.e. metabolites largely engaged in detoxification [72,73]), with a very faint production of dihydroxy metabolites (Fig. 3 and supplementary Fig. S5B) and no tetrols resulting from the hydrolysis of DNA-adducts detected in cell media. This was in line with the absence of detection of BPDE- $N^{2}$-dGuo DNA adducts, usually related to the production of the $\mathrm{B}[\mathrm{a}] \mathrm{P}$ metabolite trans-7,8-dihydrodiol, but mainly detected for higher concentrations of $\mathrm{B}[\mathrm{a}] \mathrm{P}$ than those presently tested $[8,33,43]$. Note that the profile of expression for several phase II enzymes of xenobiotic metabolism was rather similar between steatosis and non-steatosis cells (Supplementary Fig. S12). Based upon our data obtained with the antioxidant molecule thiourea and the NO scavenger CPTIO, it appeared that, under our steatotic conditions, an oxidative stress and perhaps a nitrosative 


\section{ACCEPTED MANUSCRIPT}

stress, might be the main, if not the sole, determinant of DNA damage induced by toxicant coexposure. Oxidative stress is a well-recognized "second hit" in the pathogenesis of NASH [74], and oxidative DNA damage has been previously detected in both rodent NASH models [75] and biopsies from patients with NASH [76]. Indeed, an increase in the hepatic expression of 8-oxo-7,8-dihydro-2'deoxyguanosine (8-OHdG), associated with detection of $\mathrm{ROS}\left(\mathrm{H}_{2} \mathrm{O}_{2}, \mathrm{O}_{2}{ }^{-}\right)$, lipid peroxidation products and induction of oxidative stress response genes, was reported in livers of HFD models or NASH patients [75,76]. As the effect of vitamin E (Supplementary Fig. S9B) appeared to be only partial compared to thiourea or CPTIO (Fig. 6C), lipid peroxides would be only partially involved in DNA attack and might be secondary to the formation of peroxynitrite. Indeed, a marked inhibition of the increase in the $\gamma \mathrm{H} 2 \mathrm{AX}$ staining was observed when using the catalyst FeTPPS (Fig. 6E) which allowed peroxynitrite decomposition [65], thus pointing to this species as playing a key role in the detected DNA damage. In addition, a marked increase in NO cellular content was observed in steatotic cells co-exposed to $\mathrm{B}[\mathrm{a}] \mathrm{P}$ and ethanol (Fig. 6A). A role for peroxynitrite in damaging DNA, either directly or indirectly, is well known [66,77], and has already been reported in the case of NAFLD [78], even though only few data exist regarding this latter pathology. In this context, our study might further support an important role for peroxynitrite in the pathological progression of steatosis and, to our knowledge, would be the first to evidence an impact on nuclear DNA of steatotic hepatocytes with consequences in terms of cytotoxicity. Indeed, data from Garcia-Ruiz and coworkers [78] rather highlighted peroxynitrite-mediated alterations of mitochondrial DNA in HFD-fed mice.

As stated above, metabolism of B[a]P in steatotic cells co-exposed to ethanol was altered with a significant reduction in the sum of monohydroxy and dihydroxy metabolites produced; as a consequence, significantly more $\mathrm{B}[\mathrm{a}] \mathrm{P}$ was recovered when compared to non-steatotic conditions (Fig. 3; supplementary Fig.S5A). Such a global decrease in B[a]P metabolism was previously observed by our group following a 6h-treatment with $25 \mu \mathrm{M}$ B[a]P of pre-challenged steatotic human HepaRG cells (i.e. after 14 days of co-exposure to $\mathrm{B}[\mathrm{a}] \mathrm{P} / \mathrm{ethanol}$ at relatively high concentrations $[2.5 \mu \mathrm{M}$ and $25 \mathrm{mM}$, respectively]); however in this latter case, the detected amount of the dihydroxy metabolite $\mathrm{B}[\mathrm{a}] \mathrm{P}$ trans-7,8-dihydrodiol, which is the precursor of BPDE, was found to be enhanced when 


\section{ACCEPTED MANUSCRIPT}

compared to total metabolites [8]. The differences might stem either from the higher concentrations of $\mathrm{B}[\mathrm{a}] \mathrm{P}$ used in that study or from the additional presence of CYP1B1 along with CYP1A1 in those cells. Indeed, it is worth noting that previous works have indicated that CYP1A1 would be involved in both the generation and degradation of BPDE, while CYP1B1 would only exhibit BPDE generating activity (see [79] for review). Besides, a very recent work by Uno and coworkers [11] that dealt with the effect of co-exposing Cyp1a1(-/-) mice to both Western diet and B[a]P evidenced the development of NAFLD and hepatic inflammation in these mice compared to wild-type mice, thus indicating a protective role of CYP1A1 against NAFLD pathogenesis; note that Cyp1b1 mRNA expression in Cyp1a1(-/-) mice was induced under these conditions, in contrast to what we observed (rather a decrease in Cyp1b1 expression in co-exposed steatotic cells compared to non-steatotic counterparts; supplementary Fig. S3B). The fact that we presently found a decrease of CYP1 activity associated with an enhanced toxicity in exposed steatotic cells would be in line with a protective action of CYP1A1 activation. However, what was puzzling was the inhibition of cell death with $\alpha$ NF (Fig. 2). In this context, $\mathrm{B}[\mathrm{a}] \mathrm{P}$ metabolism, even decreased, would appear as a necessary, albeit not sufficient, step in the observed toxicity. It is worth noting that $\alpha \mathrm{NF}$ is also a known antagonist of AhR. Interestingly, CH-223191, a specific antagonist of AhR, fully prevented the activation of the ethanol metabolism enzyme $\mathrm{ADH}$, elicited by the co-exposure to $\mathrm{B}[\mathrm{a}] \mathrm{P}$ and ethanol of steatotic cells (Fig. 4E). Ethanol metabolism via ADH would thus be essential to induce this toxicity, as evidenced by using the inhibitor 4-MP, thus further emphasizing the cooperative action of these two xenobiotics [29]. In order to reconcile all these data, one might postulate that, due to the fact that $\mathrm{B}[\mathrm{a}] \mathrm{P}$ was less metabolized in steatotic cells co-exposed to ethanol, there would be an increase of its level inside cells, thus favoring a more prolonged activation of $\mathrm{AhR}$, as previously proposed [80], with consequences notably in terms of ethanol metabolism (Fig. 8). It should be remembered how important ethanol metabolism via ADH is for ROS production, especially superoxide anion, via mitochondria (notably through an effect of acetaldehyde) [81]. How AhR might regulate ADH activity under our conditions remained however to be determined. Such a regulation did not seem to involve a transcriptional regulation, in contrast to previous works showing a negative control of ADH mRNA expression upon AhR activation [53]. Based upon the fact that $\mathrm{ADH}$ activity relies upon $\mathrm{NAD}^{+}$and since $\mathrm{AhR}$ can play a role in tryptophan 


\section{ACCEPTED MANUSCRIPT}

and hence $\mathrm{NAD}^{+}$synthesis [82-84], one might then hypothesize that the AhR-dependent increase in $\mathrm{ADH}$ activity might rely on an effect on $\mathrm{NAD}^{+}$synthesis. This will have to be further investigated.

In the present study, no activation of CYP2E1, another ethanol metabolism enzyme, was detected in steatotic cells co-exposed to $\mathrm{B}[\mathrm{a}] \mathrm{P}$ and ethanol; a significant reduction was even observed in these cells compared to non-steatotic counterparts (Fig. 4C). Whereas CYP2E1 activation has been previously related to NAFLD [26], such an activation might actually depend on the stage of NAFLD [85]. As we found that both CY2E1 and CYP1A activities were significantly hampered in steatotic cells, a common mechanism to explain these results was then considered, that might involve NO. Indeed, NO is known to react with heme-containing enzymes, including certain isoforms of CYPs, such as CYP2E1 and CYP1A1, thereby leading to a reduction of their activities [86-88]. Besides, as stated above, co-exposing steatotic cells to both $\mathrm{B}[\mathrm{a}] \mathrm{P}$ and ethanol elicited a marked increase in $\mathrm{NO}$ production. Using the NO scavenger CPTIO, a CYP1 activity similar to what was found in nonsteatotic cells upon co-exposure was recovered (Supplementary Fig. S10A). An increase in CYP2E1 activity was also observed in presence of CPTIO, whatever the test condition (Supplementary Fig. 10B). In this context, NO might play a pivotal role in cell death (i)-by reducing CYP1A1 activity, thereby possibly hampering $\mathrm{B}[\mathrm{a}] \mathrm{P}$ biotransformation, and inhibiting CYP2E1 activity, thus favoring ethanol metabolism via $\mathrm{ADH}$ and hence superoxide anion production by mitochondria; and (ii)-by reacting with this latter ROS species to form peroxynitrite, thereby promoting DNA damage and lipid peroxidation (Fig. 8).

Regarding the possible key role of NO, an origin for its production was looked for, leading us to identify iNOS as a source; indeed we evidenced an increase in iNOS expression using immunolocalization experiments (Fig. 7A) and found that the NOS inhibitor LNMMA significantly inhibited apoptosis (Fig. 7D), although to a lesser extent compared to the NO scavenger CPTIO (Fig. 6B). An induction of iNOS has already been associated in vivo with the pathogenesis of NASH [89], and has been suggested to be related to inflammation in this pathological situation [90]. We previously demonstrated in rat liver epithelial F258 cells that $\mathrm{B}[\mathrm{a}] \mathrm{P}$ could induce iNOS expression through AhR activation [69]. Using the AhR antagonist $\mathrm{CH}-223191$, we found here that this receptor might also be 


\section{ACCEPTED MANUSCRIPT}

involved in iNOS induction upon co-exposure to $\mathrm{B}[\mathrm{a}] \mathrm{P}$ and ethanol of steatotic cells. In parallel, a role for ROS and NFKB might also be possible in our cell model. Activation of NFkB by ROS is a wellknown process [91], and such a phenomenon has been previously evidenced in NASH, notably using in vivo rodent models [92,93]. Regarding the possible role for both $\mathrm{AhR}$ and $\mathrm{NF \kappa B}$ in iNOS activation, several hypotheses might be put forward; indeed, one might suppose either direct interactions between $\mathrm{AhR}$ and $\mathrm{NF \kappa B}$ (as already observed with the NFkB subunit RelB; [94]) to regulate iNOS mRNA expression, a regulation of the mRNA expression of AhR by NFKB by binding of RelA on AhR gene promoter [95], or an action of AhR on ROS production with consequences on $\mathrm{NF \kappa B}$ [96]. With respect to the presently reported effects, it is worth stressing that no change in mRNA expression of AhR was observed under our experimental conditions whatever the time of treatment applied (48 h or 5 days; data not shown and supplementary Fig. S4C), which would rule out any possible regulation of AhR gene expression by NFkB. Since thiourea inhibited iNOS activation and as AhR might be possibly involved in the very early (3h) activation of the ethanol-metabolizing enzyme ADH (Fig. 4E), the most likely hypothesis would then be that AhR activation would lead to a secondary NFאB activation through ROS (Figure 8).

\section{CONCLUSION}

The present study suggests for the first time that the cell death induced by co-exposing hepatocytes with prior steatosis to both $\mathrm{B}[\mathrm{a}] \mathrm{P}$ and ethanol would involve a p53- and caspasedependent apoptotic process triggered by peroxynitrite-induced DNA damage and lipid peroxidation. Cooperative mechanistic interactions between metabolism of both toxicants appeared essential, notably via an increase in ethanol metabolism by ADH possibly depending on AhR activation by $\mathrm{B}[\mathrm{a}] \mathrm{P}$, likely leading to an increase in superoxide anion production by ethanol. Besides its involvement in DNA damage and lipid peroxidation by reacting with superoxide anion to form $\mathrm{ONOO}^{-}, \mathrm{NO}$ would also play a key role through modifying $\mathrm{B}[\mathrm{a}] \mathrm{P}$ metabolism, thus leading to a potential long-lasting activation of AhR, necessary to sustain cell death signaling (Fig. 8). Based upon 


\section{ACCEPTED MANUSCRIPT}

our data, it would thus be interesting in the future to more thoroughly look at the role of NO in the pathological progression of steatosis, notably upon xenobiotic exposure, since inhibition of NO biosynthesis might help to restore normal biotransformation capacity of the liver.

\section{ACKNOWLEDGMENTS}

We wish to thank the MRic platform (SFR Biosit) for microscopy experiments, especially Stéphanie Dutertre for her technical assistance. We are very grateful to Dr Doris Cassio for providing the WIFB9 cell line. This work would not have been possible without the fruitful scientific discussions with Dr Marie-Anne Robin; we will be forever very grateful to her. AT and SB were both recipients of a fellowship from the Région Bretagne (ARED) and the Agence Nationale de la Recherche (ANR). ML was a recipient of ANSES. We also wish to thank the faculty of Pharmacy (Université de Rennes) for awarding a 2-month fellowship to AT. This work was supported by ANR [STEATOX project; "ANR13-CESA-0009”].

\section{Declarations of interest}

none

APPENDIX A. Supplemental information

\section{REFERENCES}

[1] C.E. Foulds, L.S. Treviño, B.York, C.L. Walker, Endocrine-disrupting chemicals and fatty liver disease, Nat. Rev. Endocrinol. 13 (2017) 445-457. doi: 10.1038/nrendo.2017.42.

[2] Z.M. Younossi, A.B. Koenig, D. Abdelatif, Y. Fazel, L. Henry L, et al., Global epidemiology of nonalcoholic fatty liver disease-Meta-analytic assessment of prevalence, incidence, and outcomes, Hepatology 64 (2016) 73-84. doi: 10.1002/hep.28431.

[3] C.R. Wong, M.H. Nguyen, J.K. Lim, Hepatocellular carcinoma in patients with non-alcoholic fatty liver disease, World J. Gastroenterol. 22 (2016) 8294-8303. doi:10.3748/wjg.v22.i37.8294

[4] S. Bellentani, The epidemiology of non-alcoholic fatty liver disease, Liver Int. 37 Suppl 1 (2017) 81-84. doi: 10.1111/liv.13299 


\section{ACCEPTED MANUSCRIPT}

[5] B. Le Magueresse-Battistoni, E. Labaronne, H. Vidal, D. Naville, Endocrine disrupting chemicals in mixture and obesity, diabetes and related metabolic disorders, World J. Biol. Chem. 8 (2017) 108119. doi: $10.4331 /$ wjbc.v8.i2.108

[6] C. Puoti, M.G. Elmo, D. Ceccarelli, M. Ditrinco, Liver steatosis: The new epidemic of the Third Millennium. Benign liver state or silent killer? Eur. J. Intern. Med. (2017) pii: S0953-6205(17) 302686. doi: 10.1016/j.ejim.2017.06.024

[7] H.K. Seitz, R. Bataller, H. Cortez-Pinto, B. Gao, A. Gual, et al., Alcoholic liver disease, Nat. Rev. Dis. Primers. 4 (2018) 16. doi: 10.1038/s41572-018-0014-7.

[8] S. Bucher, A. Tête, N. Podechard, M. Liamin, D. Le Guillou, et al., Co-exposure to benzo[a]pyrene and ethanol induces a pathological progression of liver steatosis in vitro and in vivo, Sci Rep. 8 (2018) 5963. doi: 10.1038/s41598-018-24403-1.

[9] N. Kazerouni, R. Sinha, C.H. Hsu, A. Greenberg, N. Rothman, Analysis of 200 food items for benzo[a]pyrene and estimation of its intake in an epidemiologic study, Food Chem. Toxicol. 39 (2001) 423-436.

[10] A.T. Vu, K.M. Taylor, M.R. Holman, Y.S. Ding, B. Hearn, et al., Polycyclic aromatic hydrocarbons in the mainstream smoke of popular U.S. cigarettes, Chem. Res. Toxicol. 28 (2015) 1616-1626. doi: 10.1021/acs.chemrestox.5b00190.

[11] S. Uno, D.W. Nebert, M. Makishima, Cytochrome P450 1A1 (CYP1A1) protects against nonalcoholic fatty liver disease caused by Western diet containing benzo[a]pyrene in mice, Food Chem. Toxicol. 113 (2018) 73-82. doi: 10.1016/j.fct.2018.01.029.

[12] A. Akhavan Rezayat, M. Dadgar Moghadam, M. Ghasemi Nour, M. Shirazinia, H. Ghodsi, et al., Association between smoking and non-alcoholic fatty liver disease: A systematic review and metaanalysis, SAGE Open Med. 6 (2018) 2050312117745223. doi: 10.1177/2050312117745223.

[13] A. Hamabe, H. Uto, Y. Imamura, K. Kusano, S. Mawatari, et al., Impact of cigarette smoking on onset of nonalcoholic fatty liver disease over a 10-year period, J. Gastroenterol. 46 (2011) 769-778. doi: 10.1007/s00535-011-0376-z.

[14] L. Miele, V. Dall'armi, C. Cefalo, B. Nedovic, D. Arzani, et al., A case-control study on the effect of metabolic gene polymorphisms, nutrition, and their interaction on the risk of non-alcoholic fatty liver disease, Genes Nutr. 9 (2014) 383. doi: 10.1007/s12263-013-0383-1.

[15] S. Zelber-Sagi, V. Ratziu, O. Oren R, Nutrition and physical activity in NAFLD: an overview of the epidemiological evidence, World J. Gastroenterol. 17 (2011) 3377-3389. doi: 10.3748/wjg.v17.i29.3377.

[16] K.E. Anderson, F.F. Kadlubar, M. Kulldorff, L. Harnack, M. Gross, et al., Dietary intake of heterocyclic amines and benzo(a)pyrene: associations with pancreatic cancer. Cancer Epidemiol Biomarkers Prev. 14 (2005) 2261-2265.

[17] P. Erkekoglu, D. Oral D, M.W. Chao, B. Kocer-Gumusel, Hepatocellular Carcinoma and Possible Chemical and Biological Causes: A Review, J. Environ. Pathol. Toxicol. Oncol. 36 (2017) 171-190. doi: 10.1615/JEnvironPatholToxicolOncol.2017020927.

[18] M. Tian, B. Zhao, J. Zhang, F.L. Martin, Q. Huang, et al., Association of environmental benzo[a]pyrene exposure and DNA methylation alterations in hepatocellular carcinoma: A Chinese case-control study, Sci. Total Environ. 541 (2016) 1243-1252. doi: 10.1016/j.scitotenv.2015.10.003. 


\section{ACCEPTED MANUSCRIPT}

[19] H. Kuper, A. Tzonou, E. Kaklamani, C.C. Hsieh, P. Lagiou, et al., Tobacco smoking, alcohol consumption and their interaction in the causation of hepatocellular carcinoma, Int. J. Cancer. 85 (2000) 498-502.

[20] W.L. Shih, H.C. Chang, Y.F. Liaw, S.M. Lin, S.D. Lee, et al., Influences of tobacco and alcohol use on hepatocellular carcinoma survival. Int. J. Cancer. 131 (2012) 2612-2621. doi: 10.1002/ijc.27508. Epub 2012 Mar 28.

[21] M.T. Donato, A. Lahoz, N. Jiménez, G. Pérez G, A. Serralta A, et al., Potential impact of steatosis on cytochrome P450 enzymes of human hepatocytes isolated from fatty liver grafts, Drug Metab. Dispos. 34 (2006) 1556-1562. doi: 10.1124/dmd.106.009670

[22] C.D. Fisher, A.J. Lickteig, L.M. Augustine, J. Ranger-Moore, J.P. Jackson et al., Hepatic cytochrome P450 enzyme alterations in humans with progressive stages of nonalcoholic fatty liver disease, Drug Metab. Dispos., 37 (2009) 2087-2094. doi: 10.1124/dmd.109.027466

[23] M.D. Merrell, N.J. Cherrington, Drug metabolism alterations in nonalcoholic fatty liver disease, Drug Metab. Rev. 43 (2011) 317-334. doi: 10.3109/03602532.2011.577781

[24] E. Cobbina, F. Akhlaghi, Non-alcoholic fatty liver disease (NAFLD) - pathogenesis, classification, and effect on drug metabolizing enzymes and transporters, Drug Metab. Rev. 17 (2017) 1-15. doi: 10.1080/03602532.2017.1293683

[25] J.A. Cichocki, S. Furuya, K. Konganti, Y.S. Luo, T.J. McDonald, et al., Impact of nonalcoholic fatty liver disease on toxicokinetics of tetrachloroethylene in Mice, J. Pharmacol. Exp. Ther. 361 (2017) 17-28. doi: 10.1124/jpet.116.238790.

[26] J. Aubert, K. Begriche, L. Knockaert, M.A. Robin, B. Fromenty, Increased expression of cytochrome P450 2E1 in nonalcoholic fatty liver disease: mechanisms and pathophysiological role, Clin. Res. Hepatol. Gastroenterol. 35 (2011) 630-637. doi: 10.1016/j.clinre.2011.04.015

[27] B.J. Song, M. Akbar, I. Jo, J.P. Hardwick, M.A. Abdelmegeed, Translational Implications of the Alcohol-Metabolizing Enzymes, Including Cytochrome P450-2E1, in Alcoholic and Nonalcoholic Liver Disease, Adv. Pharmacol. 74 (2015) 303-372. doi: 10.1016/bs.apha.2015.04.002.

[28] X. Zhang, S. Li, Y. Zhou, W. Su, X. Ruan, et al., Ablation of cytochrome P450 omegahydroxylase 4A14 gene attenuates hepatic steatosis and fibrosis, Proc. Natl. Acad. Sci. U S A. 114 (2017) 3181-3185. doi: 10.1073/pnas.1700172114.

[29] A. Collin, K. Hardonnière, M. Chevanne, J. Vuillemin, N. Podechard, et al., Cooperative interaction of benzo[a]pyrene and ethanol on plasma membrane remodeling is responsible for enhanced oxidative stress and cell death in primary rat hepatocytes, Free Radic. Biol. Med. 72 (2014) 11-22. doi: 10.1016/j.freeradbiomed.2014.03.029.

[30] S.L. Hockley, V.M. Arlt, D. Brewer, I. Giddings, D.H. Phillips, Time- and concentrationdependent changes in gene expression induced by benzo(a)pyrene in two human cell lines, MCF-7 and HepG2, BMC Genomics 7 (2006) 260. doi: 10.1186/1471-2164-7-260.

[31] S. Kalkhof, F. Dautel, S. Loguercio, S. Baumann, S. Trump, et al., Pathway and time-resolved benzo[a]pyrene toxicity on Hepa1c1c7 cells at toxic and subtoxic exposure, J. Proteome Res. 14 (2015) 164-182. doi: 10.1021/pr500957t.

[32] C. Decaens, P. Rodriguez, C. Bouchaud, D. Cassio, Establishment of hepatic cell polarity in the rat hepatoma-human fibroblast hybrid WIF-B9. A biphasic phenomenon going from a simple epithelial polarized phenotype to an hepatic polarized one, .J Cell. Science. 109 (1996) 1623-1635. 


\section{ACCEPTED MANUSCRIPT}

[33] M. Liamin, E. Boutet-Robinet, E.L. Jamin, M. Fernier, L. Khoury, et al., Benzo[a]pyrene-induced DNA damage associated with mutagenesis in primary human activated $\mathrm{T}$ lymphocytes, Biochem Pharmacol. 137 (2017) 113-124. doi: 0.1016/j.bcp.2017.04.025.

[34] N. Quesnot, S. Bucher, C. Gade, M. Vlach, E. Vene, et al., Production of chlorzoxazone glucuronides via cytochrome P4502E1 dependent and independent pathways in human hepatocytes, Arch. Toxicol. 92 (2018) 3077-3091. doi: 10.1007/s00204-018-2300-2..

[35] N. Grova, G. Salquebre, B.M. Appenzeller, Gas chromatography-tandem mass spectrometry analysis of 52 monohydroxylated metabolites of polycyclic aromatic hydrocarbons in hairs of rats after controlled exposure, Anal. Bioanal. Chem. 405 (2013) 8897-911. doi: 10.1007/s00216-013-7317$\mathrm{z}$.

[36] S.M. Staufenbiel, B.W.J.H. Penninx, Y.B. de Rijke, E.L.T. van den Akker, E.F.C. van Rossum, Determinants of hair cortisol and hair cortisone concentrations in adults, Psychoneuroendocrinology 60 (Supplement C) (2015) 182-194. doi: 10.1016/j.psyneuen.2015.06.011.

[37] N. Grova, G. Salquebre, E.M. Hardy, H. Schroeder, B.M. Appenzeller, Tetrahydroxylatedbenzo[a]pyrene isomer analysis after hydrolysis of DNA-adducts isolated from rat and human white blood cells, J. Chromatogr. A 1364 (2014) 183-91. doi: 10.1016/j.chroma.2014.08.082.

[38] J. Zielonka, J. Vasquez-Vivar, B. Kalyanaraman, Detection of 2-hydroxyethidium in cellular systems: a unique marker product of superoxide and hydroethidine, Nat. Protoc. 3 (2008) 8-21. doi: 10.1038/nprot.2007.473.

[39] J. Zielonka, B. Kalyanaraman, Small-molecule luminescent probes for the detection of cellular oxidizing and nitrating species, Free Radic. Biol. Med. 2018 Mar 19. pii: S0891-5849(18)30135-7. doi: 10.1016/j.freeradbiomed.2018.03.032. [Epub ahead of print] Review.

[40] R.R. Nazarewicz, A. Bikineyeva, S.I. Dikalov, Rapid and specific measurements of superoxide using fluorescence spectroscopy, J. Biomol. Screen. 18 (2013) 498-503. doi: $10.1177 / 1087057112468765$

[41] I. Morel, G. Lescoat, J. Cillard, N. Pasdeloup, P. Brissot, et al., Kinetic evaluation of free malondialdehyde and enzyme leakage as indices of iron damage in rat hepatocyte cultures. Involvement of free radicals, Biochem. Pharmacol. 39 (1990) 1647-1655.

[42] O. Sergent, B. Griffon, I. Morel, M. Chevanne, M.P. Dubos, et al., Effect of nitric oxide on ironmediated oxidative stress in primary rat hepatocyte culture, Hepatology 25 (1997) 122-127. doi: 10.1002/hep.510250123

[43] J.A. Holme, M. Gorria, V.M. Arlt, S. Ovrebø, A. Solhaug, et al., Different mechanisms involved in apoptosis following exposure to benzo[a]pyrene in F258 and Hepa1c1c7 cells, Chem. Biol. Interact. 167 (2007) 41-55. doi: 10.1016/j.cbi.2007.01.008

[44] K. Hardonnière, L. Huc, O. Sergent, J.A. Holme, D. Lagadic-Gossmann, Environmental carcinogenesis and $\mathrm{pH}$ homeostasis: Not only a matter of dysregulated metabolism, Semin. Cancer Biol. 43 (2017) 49-65. doi: 10.1016/j.semcancer.2017.01.001

[45] A. Solhaug, M. Refsnes, J.A. Holme, Role of cell signalling involved in induction of apoptosis by benzo[a]pyrene and cyclopenta[c,d]pyrene in Hepa1c1c7 cells, J. Cell. Biochem. 93 (2004) 1143 1154. doi: $10.1002 /$ jcb. 20251 


\section{ACCEPTED MANUSCRIPT}

[46] C. Biagini, V. Bender, F. Borde, E. Boissel, M.C. Bonnet, et al., Cytochrome P450 expressioninduction profile and chemically mediated alterations of the WIF-B9 cell line, Biol. Cell 98 (2006) 2332. doi: 10.1042/BC20050003

[47] N.W. Cornell, C. Hansch, K.H. Kim, K. Henegar. The inhibition of alcohol dehydrogenase in vitro and in isolated hepatocytes by 4-substituted pyrazoles, Arch. Biochem. Biophys. 227 (1983) 8190.

[48] K. Swaminathan, D.L. Clemens, A. Dey, Inhibition of CYP2E1 leads to decreased malondialdehyde-acetaldehyde adduct formation in VL-17A cells under chronic alcohol exposure, Life Sci. 92 (2013) 325-336. doi: 10.1016/j.lfs.2012.12.014.

[49] M. Zhao, E.W. Howard, Z. Guo, A.B. Parris, X. Yang, p53 pathway determines the cellular response to alcohol-induced DNA damage in MCF-7 breast cancer cells, PLoS One. 12 (2017) e0175121. doi: 10.1371/journal.pone.0175121.

[50] A. Naik, A. Belič, U.M. Zanger, D. Rozman, Molecular interactions between NAFLD and xenobiotic metabolism, Front Genet. 4 (2013) 2. doi: 10.3389/fgene.2013.00002

[51] D.W. Crabb, W.F. Bosron, T.K. Li, Ethanol metabolism, Pharmacol. Ther. 34 (1987) 59-73.

[52] A.I. Cederbaum, Alcohol metabolism, Clin. Liver Dis. 16 (2012) 667-685. doi: 10.1016/j.cld.2012.08.002.

[53] E.A. Attignon, A.F. Leblanc, B. Le-Grand, C. Duval, M. Aggerbeck, et al., Novel roles for AhR and ARNT in the regulation of alcohol dehydrogenases in human hepatic cells, Arch. Toxicol. 91 (2017) 313-324. doi: 10.1007/s00204-016-1700-4.

[54] H.J. Edenberg, The genetics of alcohol metabolism: role of alcohol dehydrogenase and aldehyde dehydrogenase variants, Alcohol Res. Health. 30 (2007) 5-13.

[55] A. Engin, Non-Alcoholic Fatty Liver Disease, Adv. Exp. Med. Biol. 960 (2017) 443-467. doi: 10.1007/978-3-319-48382-5_19.

[56] S. Spahis, E. Delvin, J.M. Borys, E. Levy, Oxidative Stress as a Critical Factor in Nonalcoholic Fatty Liver Disease Pathogenesis, Antioxid. Redox Signal. 26 (2017) 519-541. doi: 10.1089/ars.2016.6776.

[57] I. Kurose, H. Higuchi, S. Kato, S. Miura, H. Ishii, Ethanol-induced oxidative stress in the liver, Alcohol Clin. Exp. Res. 20(1 Suppl) (1996) 77A-85A.

[58] O. Sergent, M. Pereira, C. Belhomme, M. Chevanne, L. Huc, et al., Role for membrane fluidity in ethanol-induced oxidative stress of primary rat hepatocytes, J. Pharmacol. Exp. Ther. 313 (2005) 104111. doi: 10.1124 /jpet.104.078634

[59] M. Gorria, L. Huc, O. Sergent, A. Rebillard, F. Gaboriau, et al., Protective effect of monosialoganglioside GM1 against chemically induced apoptosis through targeting of mitochondrial function and iron transport, Biochem. Pharmacol. 72 (2006) 1343-1353. doi: 10.1016/j.bcp.2006.07.014

[60] M.J. Kelner, R. Bagnell, K.J. Welch, Thioureas react with superoxide radicals to yield a sulfhydryl compound. Explanation for protective effect against paraquat, J. Biol. Chem. 265 (1990) 1306-1311.

[61] D.S. Farmer, P. Burcham, P.D. Marin, The ability of thiourea to scavenge hydrogen peroxide and hydroxyl radicals during the intra-coronal bleaching of bloodstained root-filled teeth, Aust. Dent. J. 51 (2006) 146-152. 


\section{ACCEPTED MANUSCRIPT}

[62] D.A. Wink, J.B. Mitchell, Chemical biology of nitric oxide: Insights into regulatory, cytotoxic, and cytoprotective mechanisms of nitric oxide, Free Radic. Biol. Med. 25 (1998) 434-456. doi: 10.1016/S0891-5849(98)00092-6

[63] J.D. Laskin, D.E. Heck, C.R. Gardner, D.L. Laskin, Prooxidant and antioxidant functions of nitric oxide in liver toxicity, Antioxid. Redox Signal. 3 (2001) 261-271. doi: 10.1089/152308601300185214

[64] S. Thomas, J.E. Lowe, R.G. Knowles, I.C. Green, M.H. Green, Factors affecting the DNA damaging activity of superoxide and nitric oxide, Mutat. Res. 402 (1998) 77-84. doi: 10.1016/S00275107(97)00284-4

[65] T.P. Misko, M.K. Highkin, A.W. Veenhuizen, P.T. Manning, M.K. Stern, et al., Characterization of the cytoprotective action of peroxynitrite decomposition catalysts, J. Biol. Chem. 273 (1998) 15646-15653.

[66] C. Szabó, H. Ohshima, DNA damage induced by peroxynitrite: subsequent biological effects, Nitric Oxide. 1 (1997) 373-385. doi: 10.1006/niox.1997.0143

[67] A.L. Plant, D.M. Benson, L.C. Smith, Cellular uptake and intracellular localization of benzo(a)pyrene by digital fluorescence imaging microscopy, J. Cell. Biol. 100 (1985) 1295-1308.

[68] R. Ali, S. Trump S, I. Lehmann, T. Hanke, Live cell imaging of the intracellular compartmentalization of the contaminate benzo[a]pyrene, J. Biophotonics 8 (2015) 361-371. doi: 10.1002/jbio.201300170.

[69] K. Hardonnière, L. Huc, N. Podechard, M. Fernier, X. Tekpli, et al., Benzo[a]pyrene-induced nitric oxide production acts as a survival signal targeting mitochondrial membrane potential, Toxicol. In Vitro. 29 (2015) 1597-1608. doi: 10.1016/j.tiv.2015.06.010.

[70] F. Aktan, iNOS-mediated nitric oxide production and its regulation, Life Sci. 75 (2004) 639-653. doi: 10.1016/j.lfs.2003.10.042

[71] X.W. Zhu, J.P. Gong, Expression and role of icam-1 in the occurrence and development of hepatocellular carcinoma, Asian Pac. J. Cancer Prev. 14 (2013) 1579-1583.

[72] D. W. Nebert, Z. Shi, M. Gálvez-Peralta, S. Uno, N. Dragin, Oral Benzo[a]pyrene: Understanding Pharmacokinetics, Detoxication, and Consequences-Cyp1 Knockout Mouse Lines as a Paradigm, Mol. Pharmacol. 84 (2013) 304-313. doi: 10.1124/mol.113.086637

[73] C. Marie, M. Bouchard, R. Heredia-Ortiz, C. Viau, A. Maître, A toxicokinetic study to elucidate 3-hydroxybenzo(a)pyrene atypical urinary excretion profile following intravenous injection of benzo(a)pyrene in rats, J. Appl. Toxicol. 30 (2010) 402-410. doi:10.1002/jat.1511

[74] A.P. Rolo, J.S. Teodoro, C.M. Palmeira, Role of oxidative stress in the pathogenesis of nonalcoholic steatohepatitis, Free Radic. Biol. Med. 52 (2012) 59-69. doi: 10.1016/j.freeradbiomed.2011.10.003.

[75] E.K. Daugherity, G. Balmus, A. Al Saei, E.S. Moore, D. Abi Abdallah, et al., The DNA damage checkpoint protein ATM promotes hepatocellular apoptosis and fibrosis in a mouse model of nonalcoholic fatty liver disease, Cell Cycle, 11 (2012) 1918-1928. doi: 10.4161/cc.20259.

[76] S. Seki, T. Kitada, T. Yamada, H. Sakaguchi, K. Nakatani, et al., In situ detection of lipid peroxidation and oxidative DNA damage in non-alcoholic fatty liver diseases, J. Hepatol. 37 (2002) $56-62$.

[77] P. Pacher, J.S. Beckman, L. Liaudet, Nitric oxide and peroxynitrite in health and disease, Physiol. Rev. 87 (2007) 315-424. doi: 10.1152/physrev.00029.2006 
[78] I. García-Ruiz, P. Solís-Muñoz, D. Fernández-Moreira, M. Grau, F. Colina, et al., High-fat diet decreases activity of the oxidative phosphorylation complexes and causes nonalcoholic steatohepatitis in mice, Dis. Model Mech. 7 (2014) 1287-1296. doi: 10.1242/dmm.016766.

[79] K. Shiizaki, M. Kawanishi, T. Yagi, Modulation of benzo[a]pyrene-DNA adduct formation by CYP1 inducer and inhibitor, Genes Environ. 39 (2017) 14. doi: 10.1186/s41021-017-0076-x.

[80] Q. Shi, L. Maas, C. Veith, F.J. Van Schooten, R.W. Godschalk, Acidic cellular microenvironment modifies carcinogen-induced DNA damage and repair, Arch Toxicol 91 (2017) 2425-2441. doi: $10.1007 / \mathrm{s} 00204-016-1907-4$

[81] R. Nordmann, C. Ribière, H. Rouach, Implication of free radical mechanisms in ethanol-induced cellular injury, Free Radic. Biol. Med. 12 (1992) 219-240.

[82] K.S. Tummala, A.L. Gomes, M. Yilmaz, O. Graña, L. Bakiri L, et al., Inhibition of de novo $\mathrm{NAD}(+)$ synthesis by oncogenic URI causes liver tumorigenesis through DNA damage, Cancer Cell. 26 (2014) 826-839. doi: 10.1016/j.ccell.2014.10.002.

[83] O. Novikov, Z. Wang, E.A Stanford, A.J. Parks, A. Ramirez-Cardenas, et al., An Aryl Hydrocarbon Receptor-Mediated Amplification Loop That Enforces Cell Migration in ER-/PR-/Her2Human Breast Cancer Cells, Mol. Pharmacol. 90 (2016) 674-688. doi: 10.1124/mol.116.105361

[84] Y.S. Elhassan, A.A. Philp, G.G. Lavery, Targeting NAD+ in Metabolic Disease: New Insights Into an Old Molecule, J. Endocr. Soc. 1 (2017) 816-835. doi: 10.1210/js.2017-00092

[85] M. Orellana, R. Rodrigo, N. Varela, J. Araya, J. Poniachik, et al., Relationship between in vivo chlorzoxazone hydroxylation, hepatic cytochrome P450 2E1 content and liver injury in obese nonalcoholic fatty liver disease patients, Hepatol. Res. 34 (2006) 57-63. doi: 10.1016/j.hepres.2005.10.001

[86] J. Stadler, J. Trockfeld, W.A. Schmalix, T. Brill, J.R. Siewert, et al., Inhibition of cytochromes P4501A by nitric oxide, Proc. Natl. Acad. Sci. U S A. 91 (1994) 3559-3563.

[87] D. Gergel, V. Misík, P. Riesz, A.I. Cederbaum, Inhibition of rat and human cytochrome P4502E1 catalytic activity and reactive oxygen radical formation by nitric oxide, Arch. Biochem. Biophys. 337 (1997) 239-250.

[88] R. Vuppugalla, R. Mehvar, Hepatic disposition and effects of nitric oxide donors: rapid and concentration-dependent reduction in the cytochrome P450-mediated drug metabolism in isolated perfused rat livers, J. Pharmacol. Exp. Ther. 310 (2004) 718-727. doi: 10.1124/jpet.104.065557

[89] K. Fujita, Y. Nozaki, M. Yoneda, K. Wada, H. Takahashi, et al., Nitric oxide plays a crucial role in the development/progression of nonalcoholic steatohepatitis in the choline-deficient, 1-amino aciddefined diet-fed rat model, Alcohol Clin. Exp. Res. 34 Suppl 1 (2010) S18-24. doi: 10.1111/j.15300277.2008.00756.x.

[90] Y. Iwakiri, M.Y. Kim, Nitric oxide in liver diseases, Trends Pharmacol. Sci. 36 (2015) 524-536. doi: 10.1016/j.tips.2015.05.001.

[91] H. Kamata, H. Hirata, Redox regulation of cellular signaling, Cell Signal. 11 (1999) 1-14.

[92] H.J. Park, J.Y. Lee, M.Y. Chung, Y.K. Park, A.M. Bower, et al., Green tea extract suppresses $\mathrm{NF \kappa B}$ activation and inflammatory responses in diet-induced obese rats with nonalcoholic steatohepatitis, J. Nutr. 142 (2012) 57-63. doi: 10.3945/jn.111.148544.

[93] J. Li, T.N. Sapper, E. Mah, S. Rudraiah, K.E. Schill, et al., Green tea extract provides extensive Nrf2-independent protection against lipid accumulation and NFKB pro- inflammatory responses during 


\section{ACCEPTED MANUSCRIPT}

nonalcoholic steatohepatitis in mice fed a high-fat diet, Mol. Nutr. Food Res. 60 (2016) 858-870. doi: 10.1002/mnfr.201500814.

[94] C.F. Vogel, E. Sciullo, W. Li, P. Wong, G. Lazennec, et al., RelB, a new partner of aryl hydrocarbon receptor-mediated transcription, Mol. Endocrinol. 21 (2007) 2941-55. doi: $10.1210 /$ me.2007-0211

[95] C.F. Vogel, E.M. Khan, P.S. Leung, M.E. Gershwin, W.L. Chang, et al., Cross-talk between aryl hydrocarbon receptor and the inflammatory response: a role for nuclear factor- $\mathrm{kB}, \mathrm{J}$. Biol. Chem. 289 (2014) 1866-1875. doi: 10.1074/jbc.M113.505578.

[96] R.H. Elbekai, H.M. Korashy, K. Wills, N. Gharavi, A.O. El-Kadi, Benzo[a]pyrene, 3methylcholanthrene and beta-naphthoflavone induce oxidative stress in hepatoma hepa 1c1c7 Cells by an AHR-dependent pathway, Free Radic. Res. 38 (2004) 1191-1200. doi: $10.1080 / 10715760400017319$

Fig 1. Role for caspases 3/7 and DNA damage-related p53 activation in the cell death of steatotic WIF-B9 cells co-exposed to B[a]P and ethanol. Non-steatotic or steatotic hepatocytes were treated or not (C; treated with DMSO) with $5 \mathrm{mM}$ ethanol (E), $10 \mathrm{nM} \mathrm{B}$ [a]P (B) or a combination of both toxicants (BE) for 5 days. Apoptosis was evaluated by counting cells with condensed/fragmented chromatin after nuclear staining with Hoechst 33342 in presence or not of a pan-caspase inhibitor zVAD $(10 \mu \mathrm{M})(\mathbf{A})$ and by analyzing DEVDase activities of caspases $3 / 7$ by spectrofluorimetry (B). DNA damage was evaluated by analyzing the phosphorylation of H2AX on Ser139 $(\gamma \mathrm{H} 2 \mathrm{AX})$ by immunocytochemistry $(\mathbf{C})$. Evaluation of p53 involvement in cell death was realized by testing the effect of the p53 inhibitor pifithrin $\alpha$ (PFT; $10 \mu \mathrm{M}$ ) on apoptosis (D). Fluorescence microscopy analysis of $\mathrm{p} 53$ expression and localization (E). mRNA expression of $p 21$, a known gene target of $\mathrm{p} 53$, was evaluated by RT-qPCR. Data were given relative to mRNA level determined in control cells (F). All results are means \pm SD for at least three independent cultures. *: Significantly different from condition without inhibitor (zVAD or PFT). a: Significantly different from corresponding control (with or without steatosis). b: Significantly different from B[a]P alone. \#: Significantly different from condition without prior steatosis.

Fig 2. Involvement of $\mathrm{B}[\mathrm{a}] \mathrm{P}$ metabolism in the cell death induced by $\mathrm{B}[\mathrm{a}] \mathrm{P} / \mathrm{ethanol}$ co-exposure in steatotic WIF-B9 cells. Non-steatotic or steatotic hepatocytes were treated or not $(\mathrm{C}$; treated with DMSO) with $5 \mathrm{mM}$ ethanol (E), $10 \mathrm{nM} \mathrm{B}[\mathrm{a}] \mathrm{P}(\mathrm{B})$ or a combination of both toxicants (BE) for 5 days, in presence or not of inhibitor. The involvement of $\mathrm{B}[\mathrm{a}] \mathrm{P}$ metabolism was tested by analyzing the effects of the AhR/CYP1 inhibitor $\alpha \mathrm{NF}(10 \mu \mathrm{M})$ on (A) apoptosis evaluated following Hoechst 33342 staining, (B) intracellular ATP content and (C) DNA damage evaluated by counting cells positive for $\gamma \mathrm{H} 2 \mathrm{AX}$ staining. (D) Cyplal mRNA expression was evaluated by RT-qPCR, and given relative to mRNA level in control non-steatotic cells. (E) CYP1A1 protein level was evaluated by westernblotting analysis. Representative western blots and relative band density quantification are illustrated. 


\section{ACCEPTED MANUSCRIPT}

(F) CYP1 enzyme activity was assessed by measuring EROD activity from intact cells. Results are means \pm SD for at least three independent cultures. *: Significantly different from condition without $\alpha N F$. a: Significantly different from corresponding control (with or without steatosis). b: Significantly different from B[a]P alone. \#: Significantly different from condition without prior steatosis.

Fig 3. Formation of $\mathrm{B}[\mathrm{a}] \mathrm{P}$ metabolites was altered by steatosis and upon ethanol co-exposure. Non-steatotic or steatotic hepatocytes were treated with $10 \mathrm{nM} \mathrm{B}[\mathrm{a}] \mathrm{P}$ alone or in combination with 5 $\mathrm{mM}$ ethanol for 5 days. B[a]P metabolites in culture media were analyzed by gas chromatography tandem mass-spectrometry. Results are quoted as proportion of $\mathrm{B}[\mathrm{a}] \mathrm{P}$ relatively to total $\mathrm{OH}-$ and total diOH-B[a]P metabolites detected under the different conditions (cf. Supplementary supplementary Table S2 for values). Results are means \pm SD for at least three independent cultures.

Fig 4. Involvement of ethanol metabolism in the cell death induced by B[a]P/ethanol co-exposure in steatotic WIF-B9 cells. Non-steatotic or steatotic hepatocytes were treated or not (C; treated with DMSO) with $5 \mathrm{mM}$ ethanol (E), $10 \mathrm{nM} \mathrm{B}$ [a]P (B) or a combination of both toxicants (BE) for 5 days (A-C, F) or $3 \mathrm{~h}(\mathrm{D}, \mathrm{E})$, in presence or not of inhibitor. The involvement of ethanol metabolism was analyzed by testing the effect of the CYP2E1/ADH inhibitor 4-MP $(500 \mu \mathrm{M})$, on (A) apoptosis after Hoechst 33342 staining, and (B) DNA damage evaluated by counting cells positive for $\gamma \mathrm{H} 2 \mathrm{AX}$ staining. (C) CYP2E1 activity was assessed by HPLC analyses (UV detection) of the formation of OCZX. ADH activity was evaluated by measuring the NADH production by spectrophotometry in the absence (D) or presence (E) of the AhR inhibitor CH-223191 (CH; $3 \mu \mathrm{M})$. This activity was given relative to control cells. (F) Involvement of AhR in apoptosis was evaluated after co-treatment with $\mathrm{CH}$. Results are means \pm SD for at least three independent cultures. *: Significantly different from condition without inhibitor (4-MP or $\mathrm{CH}$ ). a: Significantly different from corresponding control (with or without steatosis). b: Significantly different from B[a]P alone. \#: Significantly different from condition without prior steatosis.

Fig 5. Involvement of oxidative stress in the cell death induced by $\mathrm{B}[\mathrm{a}] \mathrm{P} / \mathrm{ethanol}$ co-exposure in steatotic WIF-B9 cells. Non-steatotic or steatotic hepatocytes were treated or not $(\mathrm{C}$; treated with DMSO) with $5 \mathrm{mM}$ ethanol (E), $10 \mathrm{nM} \mathrm{B}[\mathrm{a}] \mathrm{P}(\mathrm{B})$ or a combination of both toxicants (BE) for 5 days, in presence or not of antioxidant. The involvement of oxidative stress in toxicity was evaluated by testing the effects of the antioxidant molecule thiourea $(6.25 \mathrm{mM})$ on $(A)$ apoptosis after Hoechst 33342 staining, and (C) DNA damage evaluated by counting cells positive for $\gamma \mathrm{H} 2 \mathrm{AX}$ staining. (B) Lipid peroxidation was assessed by measuring the production of malondialdehyde (MDA) by HPLC. (D) The superoxide anion production was assessed by the measurement in fluorescence of 2-OH ethidium using DHE probe. Results are means \pm SD for at least three independent cultures. *: Significantly different from condition without thiourea. a: Significantly different from corresponding 


\section{ACCEPTED MANUSCRIPT}

control (with or without steatosis). b: Significantly different from B[a]P alone. \#: Significantly different from condition without prior steatosis.

Fig 6. Involvement of nitric oxide and peroxynitrite in the cell death induced by $B[a] P / e t h a n o l$ co-exposure in steatotic WIF-B9 cells. Non-steatotic or steatotic hepatocytes were treated or not (C; treated with DMSO) with $5 \mathrm{mM}$ ethanol (E), $10 \mathrm{nM} \mathrm{B}[\mathrm{a}] \mathrm{P}(\mathrm{B})$ or a combination of both toxicants (BE) for 5 days, in presence or not of the NO scavenger CPTIO $(25 \mu \mathrm{M})$. (A) NO production was assessed by EPR detection of dinitrosyl iron complex (DNIC) signal in cells (AU: arbitrary unit). The involvement of NO in toxicity was analyzed by testing the effects of CPTIO on (B) apoptosis after Hoechst 33342 staining and (C) DNA damage evaluated by counting cells positive for $\gamma \mathrm{H} 2 \mathrm{AX}$ staining. The involvement of peroxynitrite in toxicity was tested by analyzing the effects of FeTPPS $(2.5 \mu \mathrm{M})$, a peroxynitrite decomposition catalyst, on (D) apoptosis after Hoechst 33342 staining, and (E) DNA damage evaluated by counting cells positive for $\gamma-\mathrm{H} 2 \mathrm{AX}$ staining. Results are means $\pm \mathrm{SD}$ for at least three independent cultures. *: Significantly different from condition without inhibitor. a: Significantly different from corresponding control (with or without steatosis). b: Significantly different from B[a]P alone. \#: Significantly different from condition without prior steatosis.

Fig 7. Effects of $\mathrm{B}[\mathrm{a}] \mathrm{P} / \mathrm{ethanol}$ co-exposure on iNOS expression in steatotic WIF-B9 cells and role for AhR and NFkB in these effects. Non-steatotic or steatotic hepatocytes were treated or not (C; treated with DMSO) with $5 \mathrm{mM}$ ethanol (E), $10 \mathrm{nM} \mathrm{B[a]P(B)}$ or a combination of both toxicants (BE) for 2 (A-C) or 5 days (B), in presence or not of inhibitor. (A) iNOS expression was analyzed by immunofluorescence. AhR, NFkB and ROS involvement was tested by using $\mathrm{CH}-223191(\mathrm{CH}, 3 \mu \mathrm{M})$, Bay 11-7082 (Bay, $10 \mu \mathrm{M})$ or thiourea $(6.25 \mathrm{mM})$, respectively. $(\mathbf{B}, \mathbf{C})$ Quantification of the fluorescence intensity corresponding to iNOS staining versus DAPI (nuclear) staining. (D) The involvement of iNOS in cell death was tested by using LNMMA $(500 \mu \mathrm{M})$, a NOS inhibitor, after Hoechst 33342 staining. Results are means \pm SD for at least three independent cultures. *: Significantly different from condition without inhibitor. a: Significantly different from corresponding control (with or without steatosis). b: Significantly different from B[a]P alone.

Fig 8. Proposed signaling pathways involved in the cell death induced by $B[a] P / e t h a n o l$ coexposure in steatotic WIF-B9 cells. AhR activation by $\mathrm{B}[\mathrm{a}] \mathrm{P}$ would induce an increase in ADH activity leading to enhanced ethanol metabolism. This would then result in ROS-dependent NFKB activation, thus leading to increased iNOS expression and hence NO production. NO and superoxide anion would then form peroxynitrite, thus leading to oxidative damage to lipids (LPO) and DNA. Both could participate to the development of cell death, notably via the p53 pathway for DNA damage. In parallel, NO may inhibit CYP1A1 activity, which would decrease $\mathrm{B}[\mathrm{a}] \mathrm{P}$ metabolism, thus possibly favoring long-term activation of AhR, thereby increasing $\mathrm{ADH}$ activity. 
Figure 1
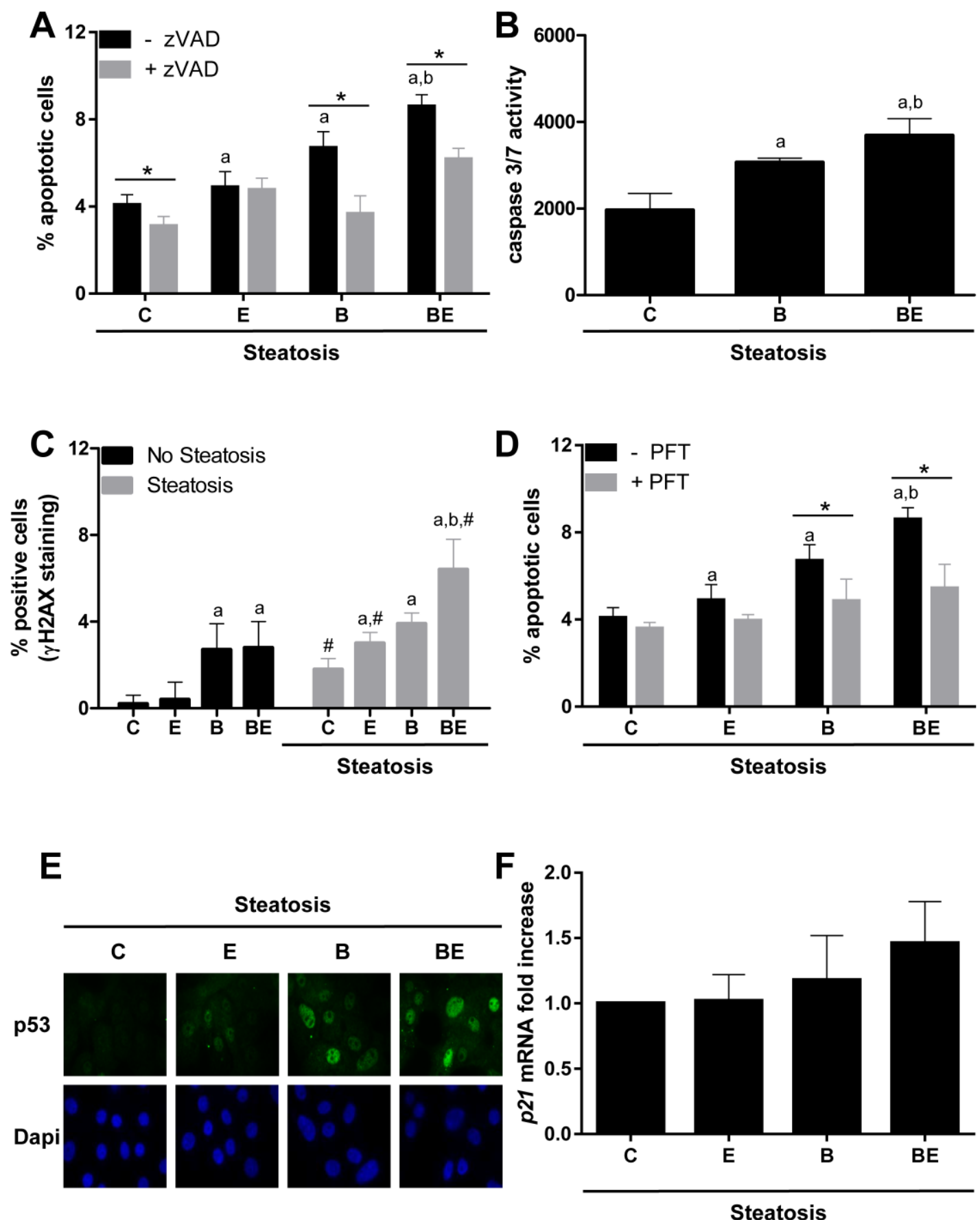
Figure 2
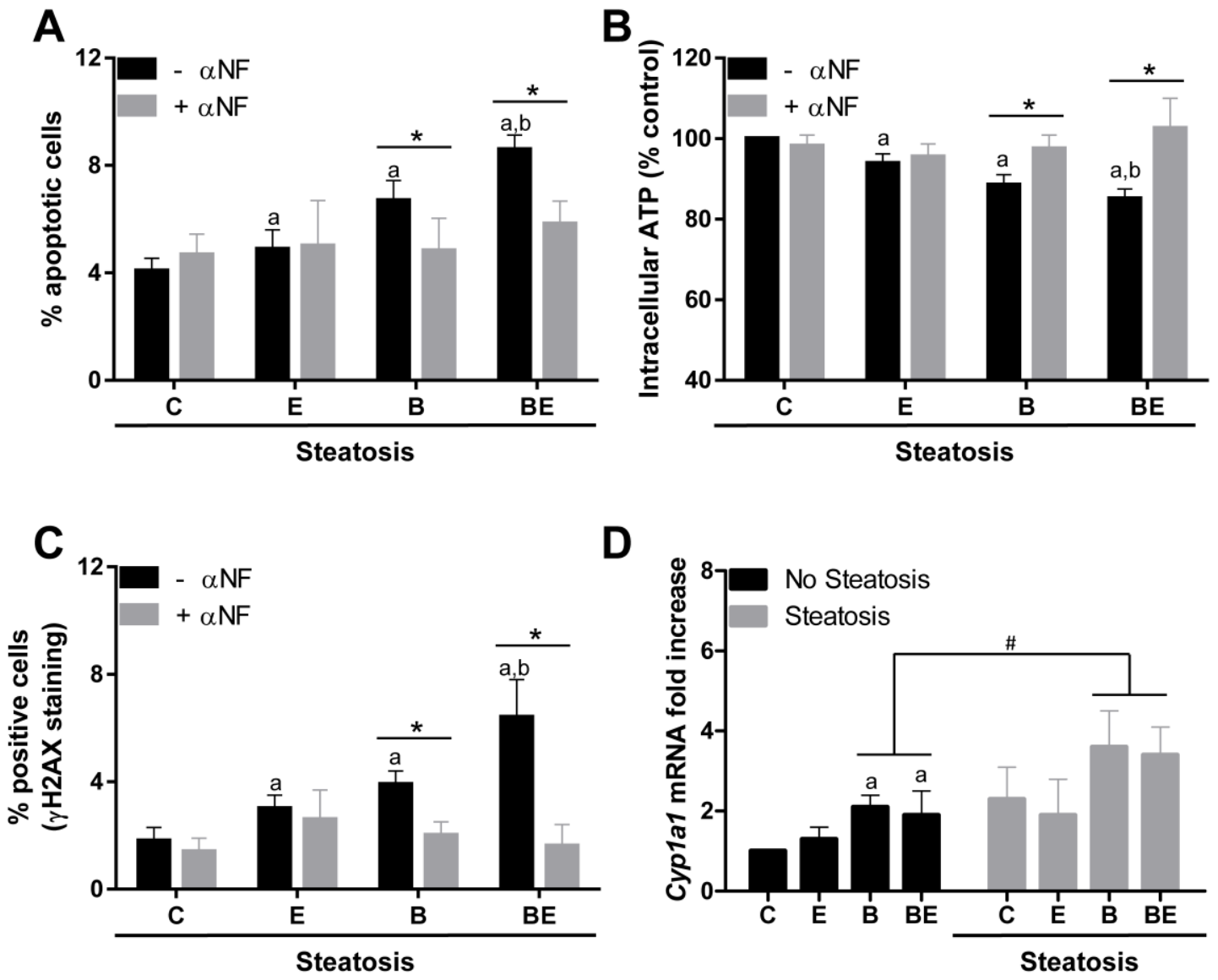

D
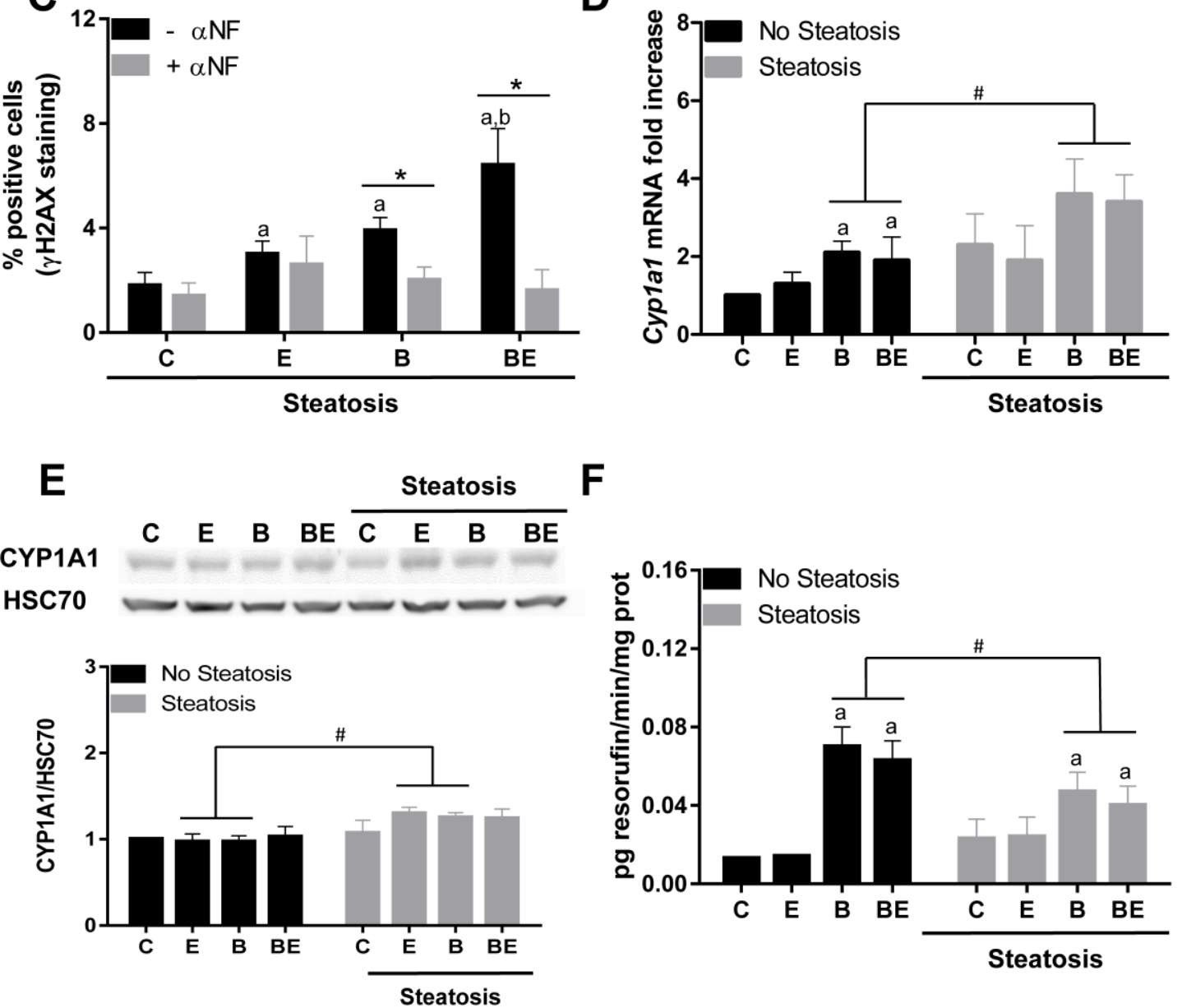


\section{Figure 3}

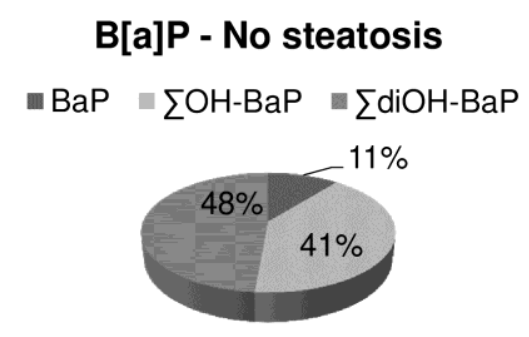

B[a]P- Steatosis

$\| \mathrm{BaP}=\Sigma \mathrm{OH}-\mathrm{BaP}=\Sigma \mathrm{diOH}-\mathrm{BaP}$

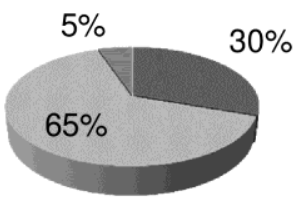

\section{$\mathrm{B}[\mathrm{a}] \mathrm{P} / \mathrm{EtOH}$ - No steatosis}

$\square \mathrm{BaP}=\Sigma \mathrm{OH}-\mathrm{BaP}=\Sigma \mathrm{diOH}-\mathrm{BaP}$

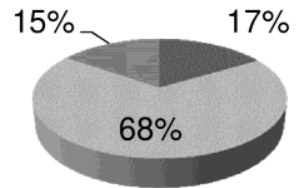

\section{$\mathrm{B}$ [a]P/EtOH - Steatosis}

$\square \mathrm{BaP} \backsim \sum \mathrm{OH}-\mathrm{BaP}=\sum \mathrm{diOH}-\mathrm{BaP}$

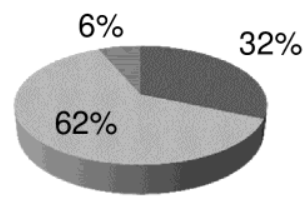


Figure 4

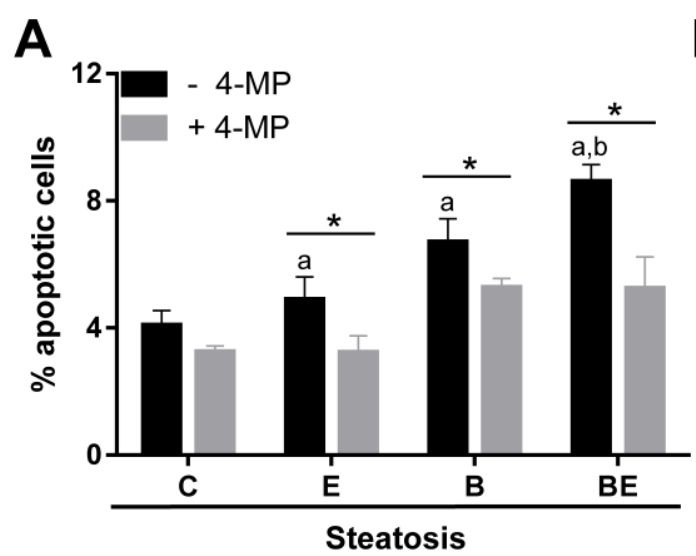

B

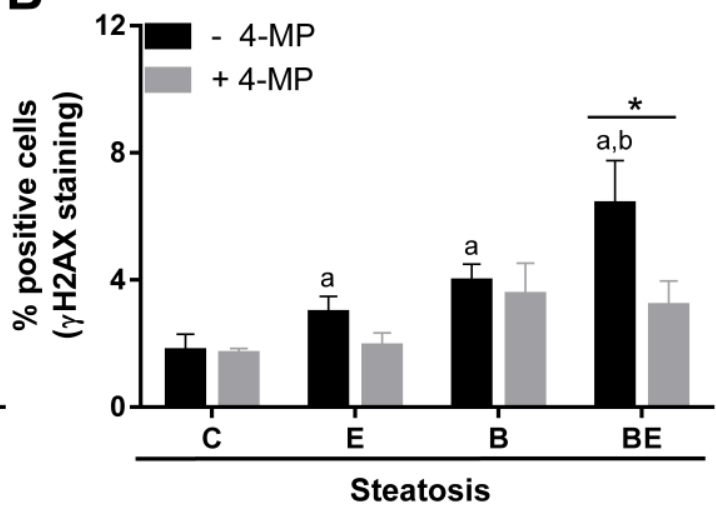

C

D
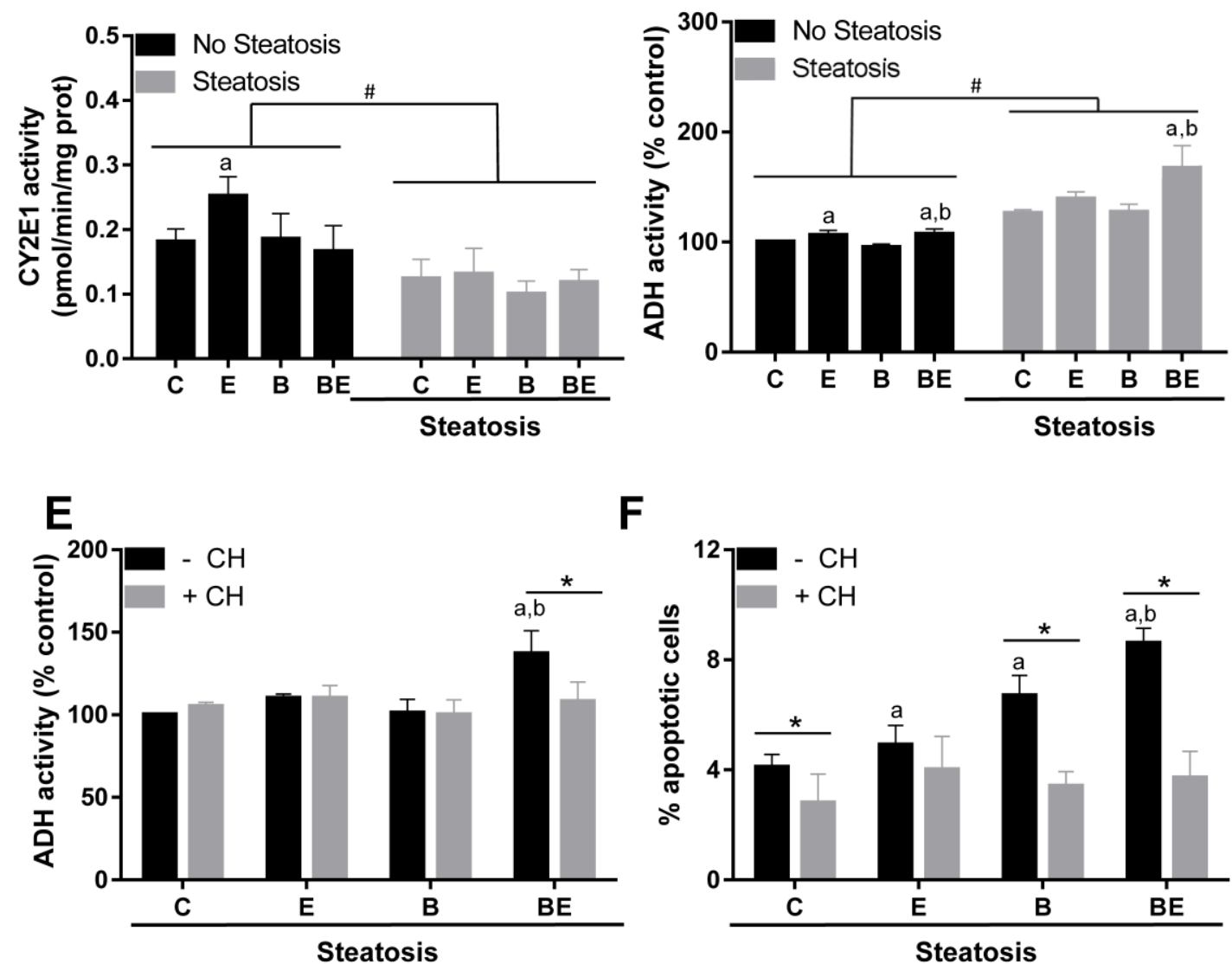

F

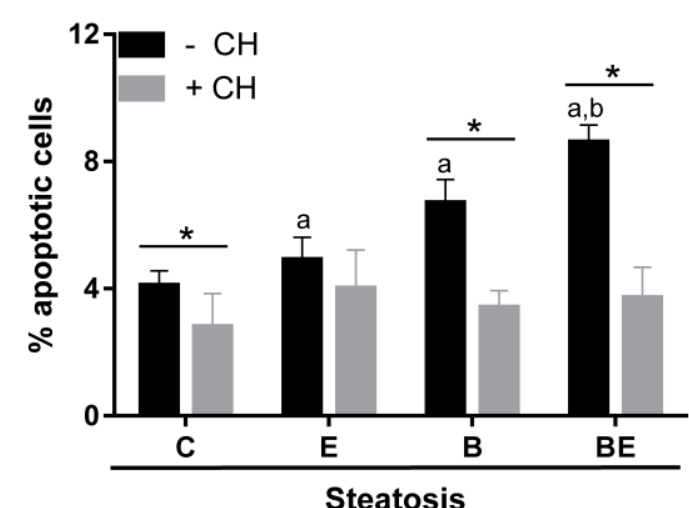


Figure 5
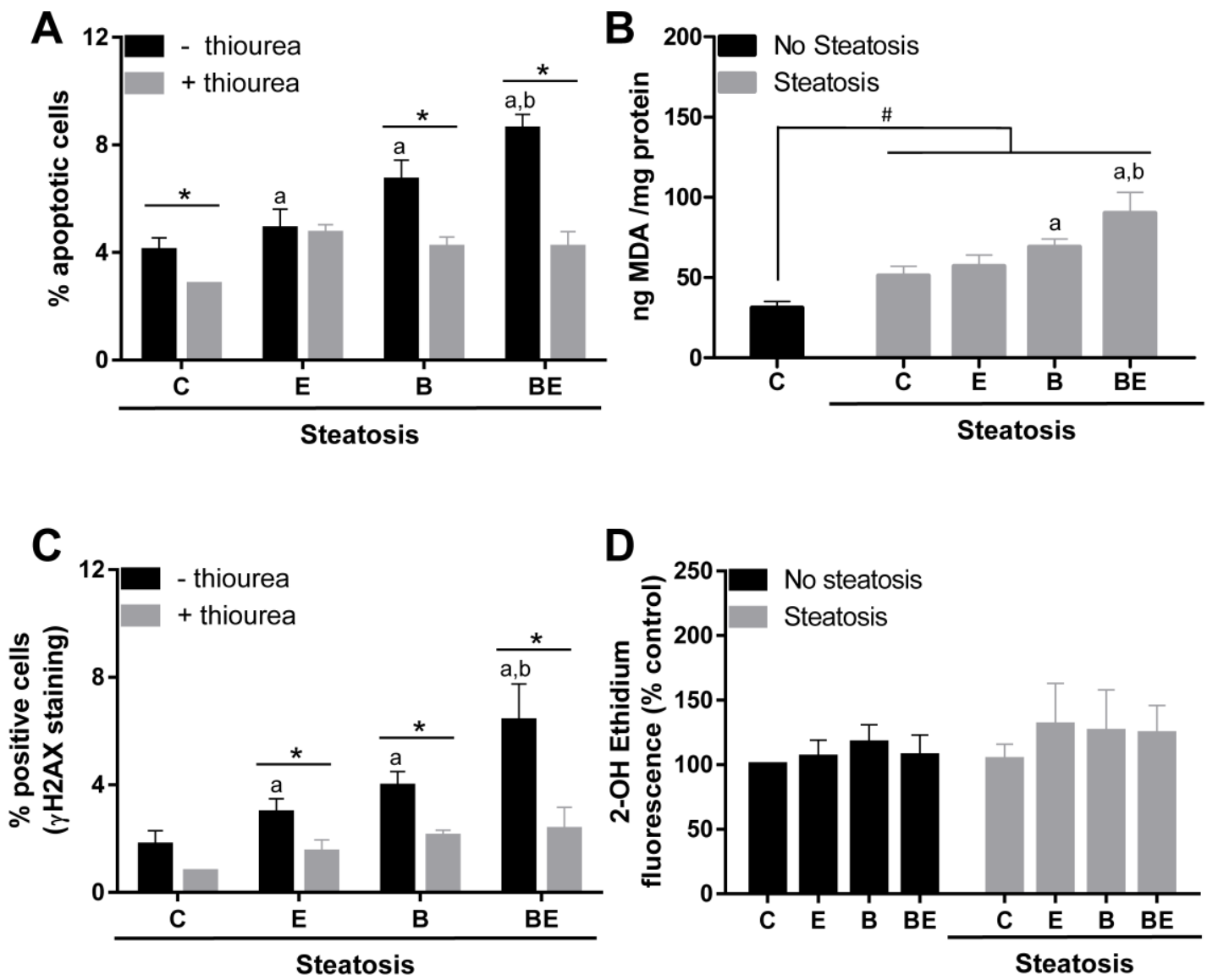
Figure 6

A

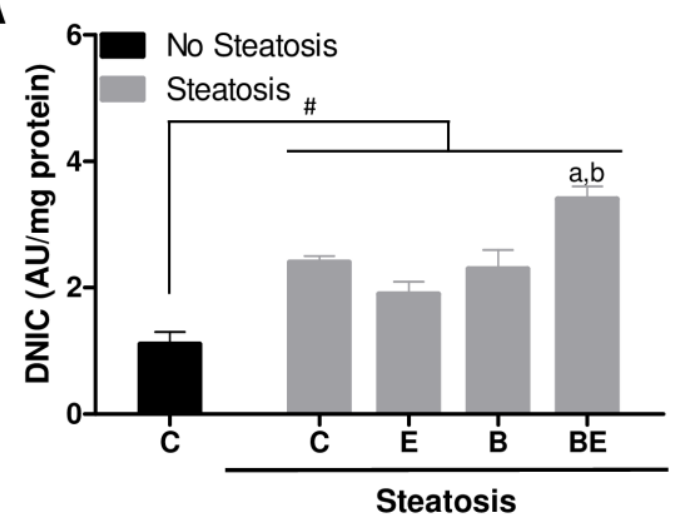

C

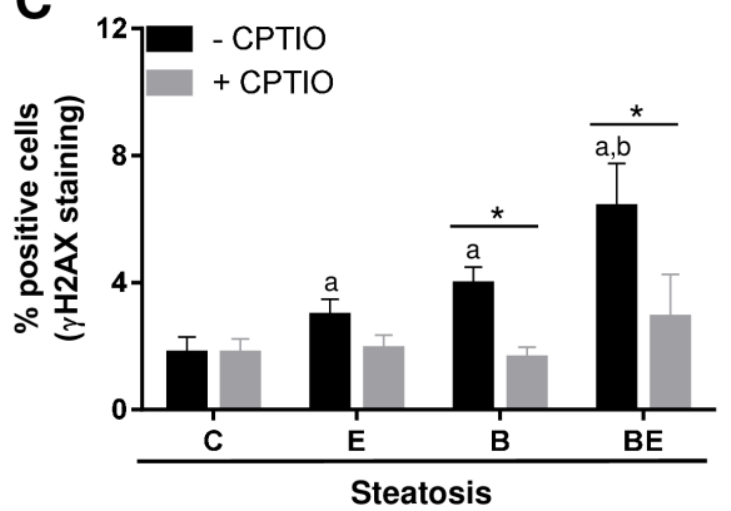

E

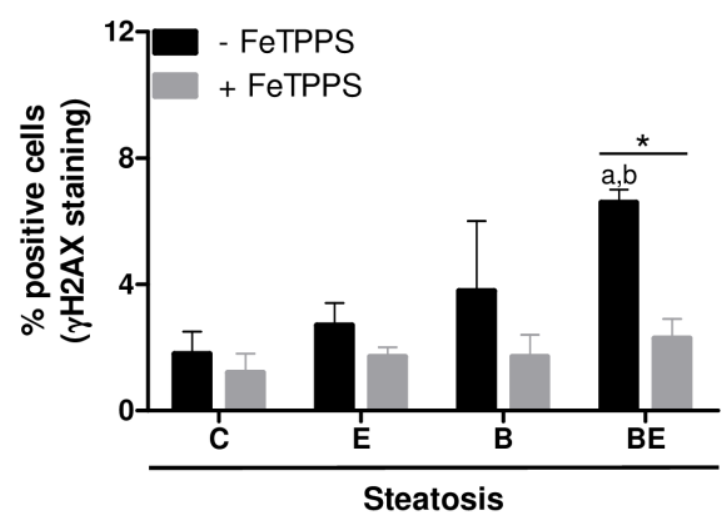

B

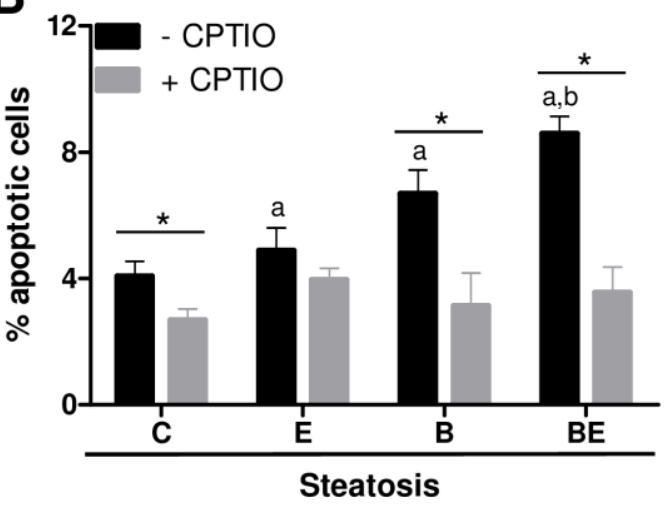

D

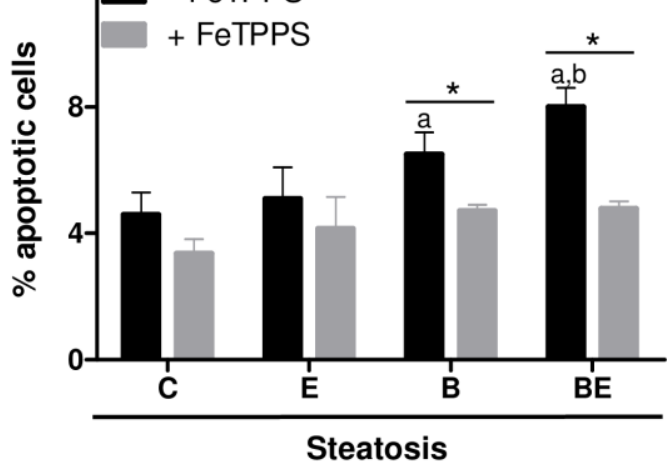




\section{ACCEPTED MANUSCRIPT}

\section{Figure 7}

A

No steatosis

Steatosis

C

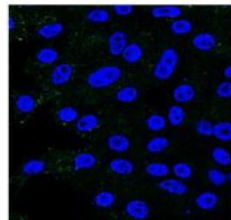

BE
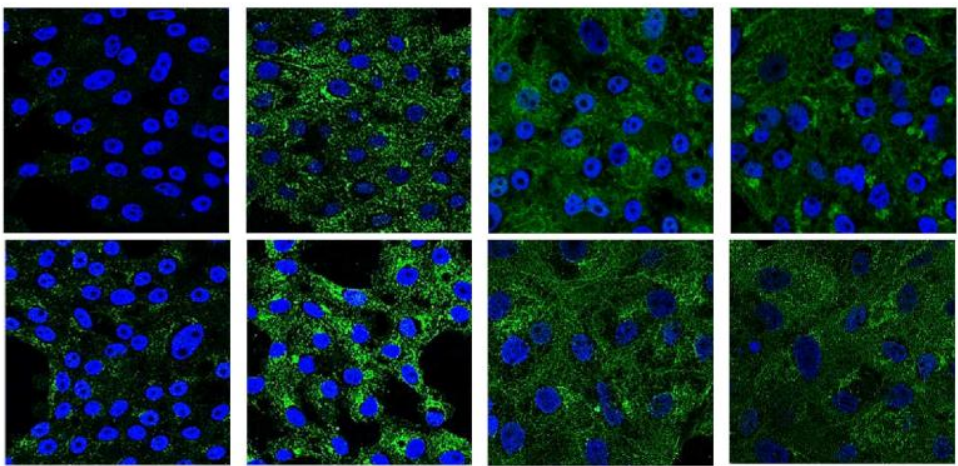

+ Bay

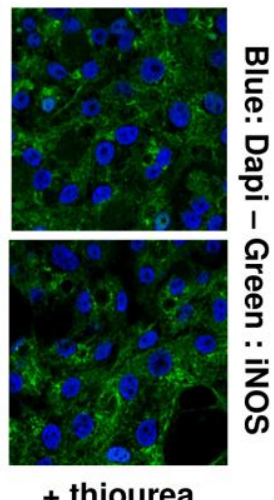

B

C
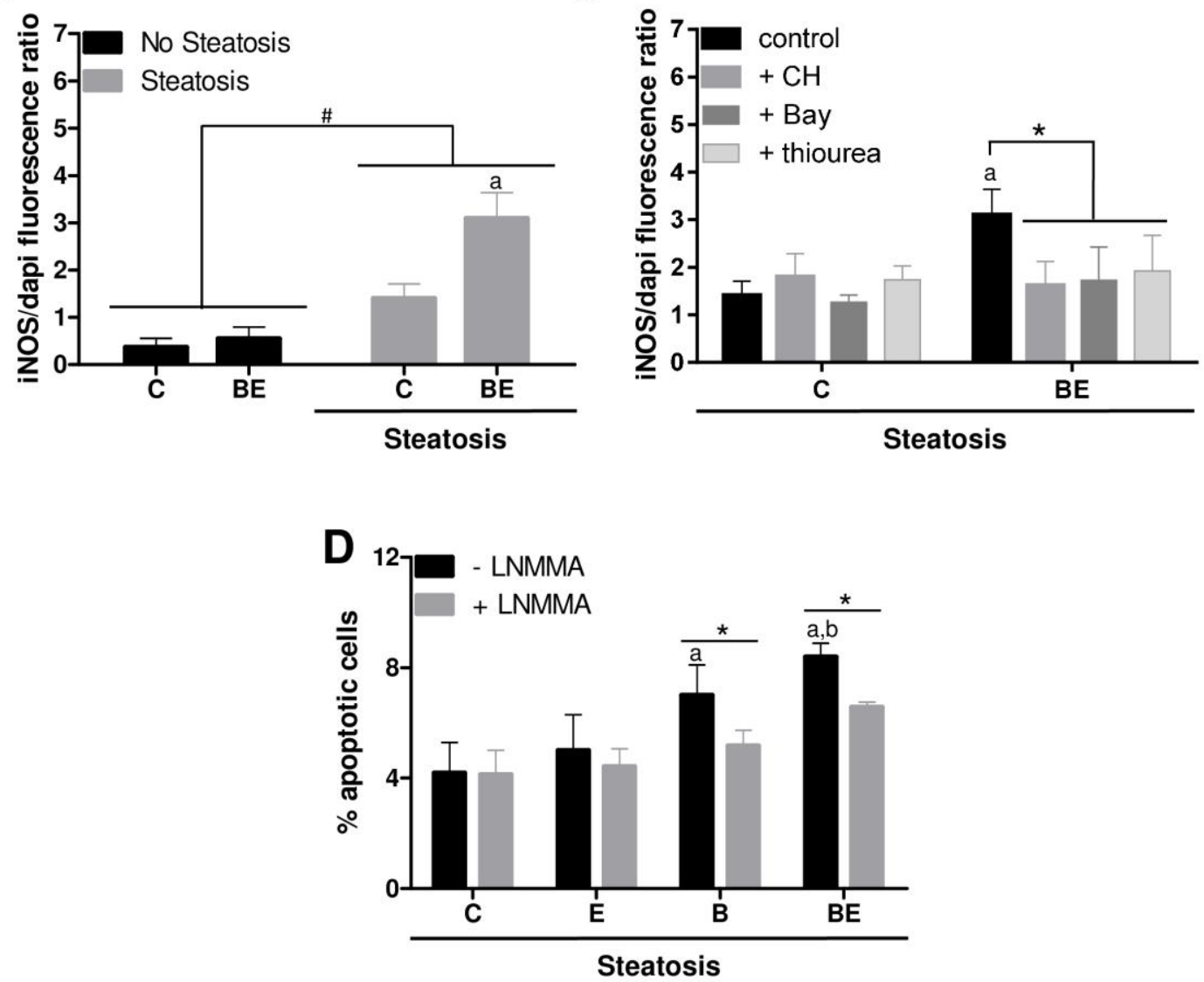
Figure 8

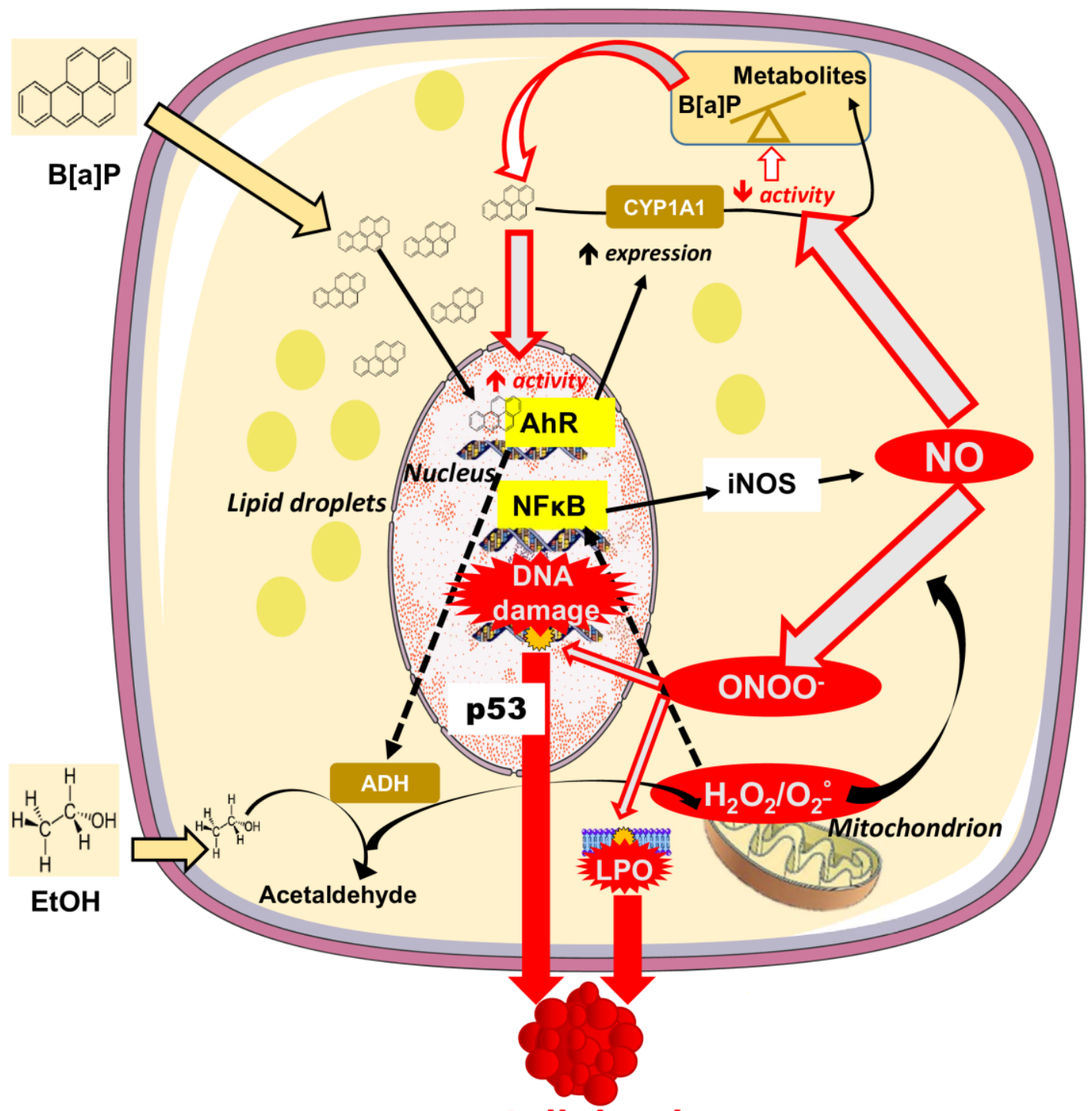

Cell death 
Figure 8

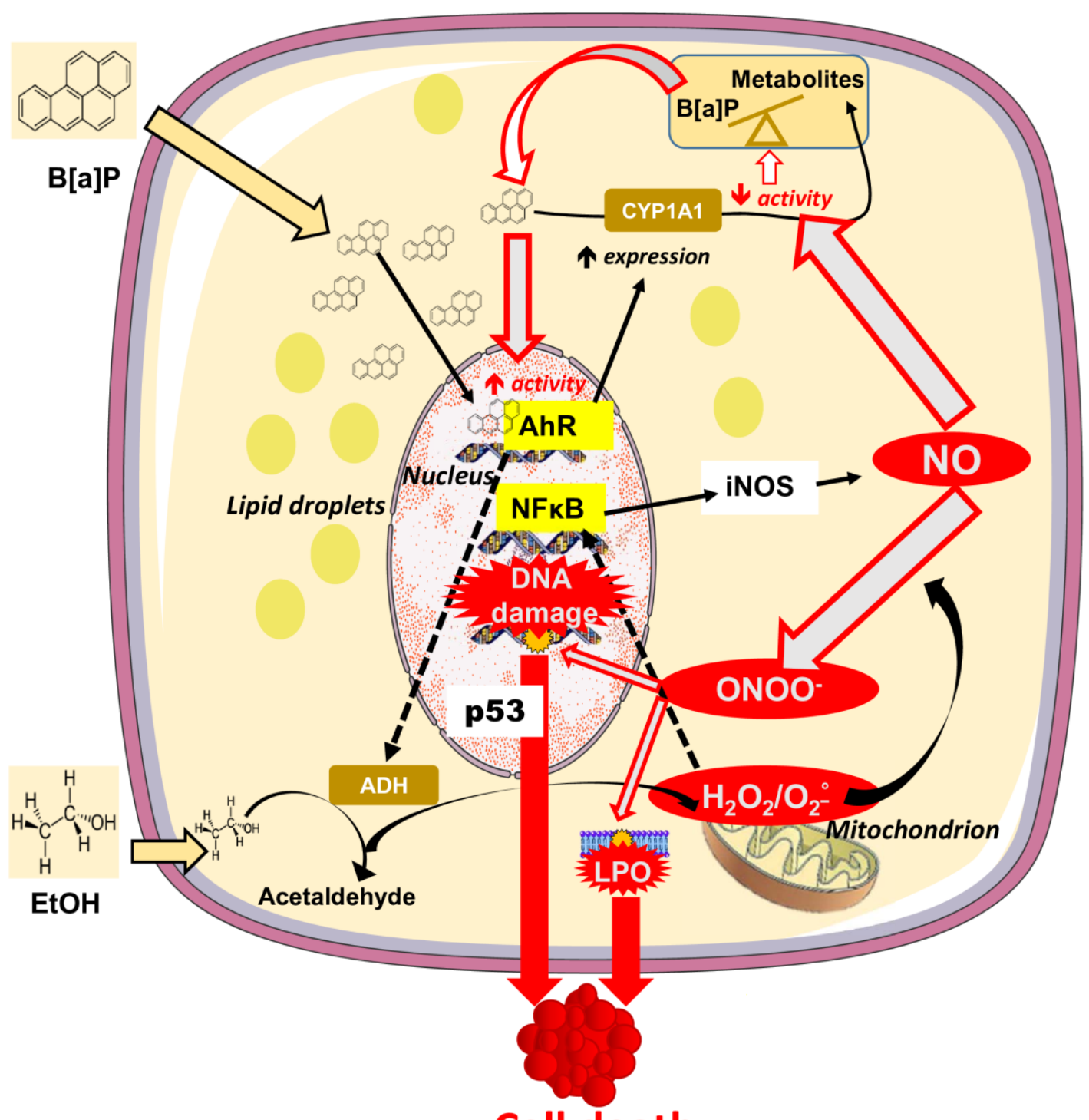

Cell death 


\section{ACCEPTED MANUSCRIPT}

\section{HIGHLIGHTS}

- 1-Death of steatotic hepatocytes co-exposed to $\mathrm{B}[\mathrm{a}] \mathrm{P} / \mathrm{EtOH}$ involves toxicant metabolism.

- 2-B[a]P-activated AhR would enhance ethanol metabolism by ADH in steatotic cells.

- 3-AhR and NFKB would be involved in iNOS induction, thus leading to NO production.

- 4-NO, by reducing CYP1 activity, decreases B[a]P metabolism, thus favoring AhR pathway.

- 5-Death of co-exposed steatotic cells involves a peroxynitrite-dependent DNA damage. 